\title{
Parerga to the Stadiasmus Patarensis (16): The Roads, Settlements and Territories
}

\author{
Fatih ONUR*
}

in memory of Prof. Dr. Sencer ŞAHİN**

In this paper, I discuss some issues concerning the relationship between roads, settlements and territories recorded in the Stadiasmus Patarensis (SP). Accepting that the SP was not a journey guide and that it just provided the length of the roads (R) constructed or renovated, and of course measured, between almost all of the major and some minor settlements, I propose: firstly, that the roads between the settlements were from and into the settlements' town zones; secondly, that the composition of the road list took account of the territories of the settlements; thirdly, that all the settlements mentioned in the SP had an independence, which might have varied in different status. The paper opens by discussing the use of prepositions and articles in the SP, before addressing the courses of the roads. I shall then treat the probable start and end points of the roads, and dedicate a final section to the political status of the settlements and the related territorial issues.

Before addressing these points, I believe that it should be firstly and precisely determined what was meant by the use of ódó publications, we have called these road connections, the "routes" (itinera) between settlements,

\footnotetext{
${ }^{*}$ Assoc. Prof. Fatih Onur, Akdeniz University, Faculty of Letters, Dept. of Ancient Languages and Cultures, Campus 07058 Antalya (fatihonur@akdeniz.edu.tr).

This contribution results from the "Stadiasmus Patarensis" field surveys directed by the late Prof. Sencer Şahin until 2014 and hereafter by Prof. N. Eda Akyürek Şahin with the permission from the Turkish Ministry of Culture and Tourism. These field surveys have been supported by "The Scientific and Technological Research Council of Turkey" (TÜBİTAK, project no. 108K437), in 2009-2011 and by the Akdeniz University Scientific Research Projects Coordination Unit (project no.: SBA-2015-937, conducted by Prof. N. Eda Akyürek Şahin) from 2015 onwards. I am very grateful to the Research Center for Anatolian Civilizations at Koç University for granting me a Senior Fellowship between the $15^{\text {th }}$ September 2013 and the $1^{\text {st }}$ February 2014 for my project entitled "Stadiasmus Patarensis: The Monument $\&$ the Results of the Field Surveys in Lycia". The award I was given by the Science Academy in Turkey through "Young Scientist Awards Program (BAGEP)" provided invaluable support to my research. I thank T. Michael P. Duggan for improving the English of this paper and his remarkable observation; and Stephen Mitchell for his remarks. I should also thank Selim F. Adalı for his companionship during the composition of this contribution and for his comments on the manuscript. A Turkish version of this article has been published: "F. Onur, Stadiasmus Patarensis'te Yollar, Yerleşimler ve Teritoryumlar, in: N. E. Akyürek Şahin - M. Ertan Yıldız - H. Uzunoğlu (edd.), Eskiçağ Yazıları 8 [AKRON 10], İstanbul 2016, 73-125”.

** This article was originally submitted for publication in the Festschrift "Vir Doctus Anatolicus. Studies in memory of Sencer Şahin", which has now become a Gedenkschrift, but it has been withdrawn for several reasons. The issues included within this contribution were written prior to the death of Sencer Şahin and were discussed several times with him. I take this opportunity to commemorate Prof. Dr. Sencer Şahin, my most esteemed doctoral supervisor, with respect and regret for his passing.
} 
while in reality it was not the intention of the text of the SP to provide a journey planner (see the explanations below in p. 97). Iter means "way; course; journey", while via indicates the "road" itself. There is a clear distinction between these terms. The evidence to understand this comes straight

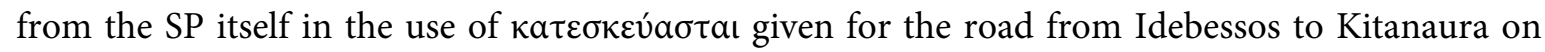

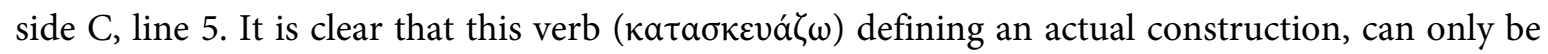

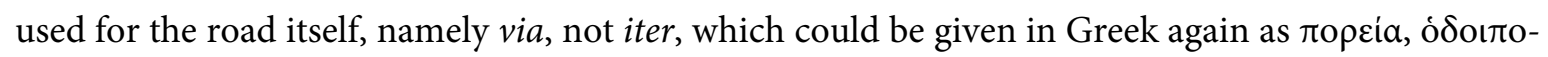

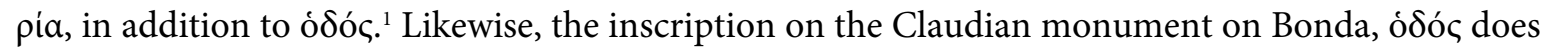

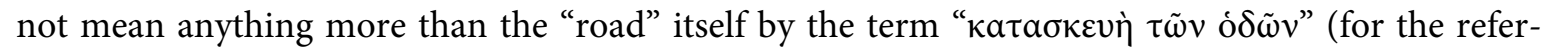
ences to this inscription see fn. 30 ).

\section{Prepositions and Articles}

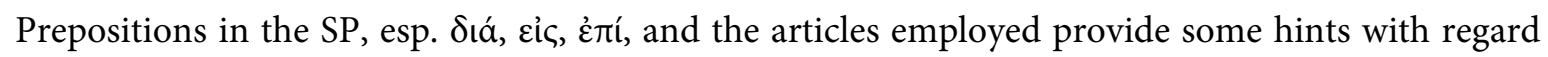
to the courses of these roads. What is clear in the whole text of the SP is that the settlements never have articles, as is typical in Greek. The articles can be seen in different cases, and relate to natural formations, mountain names, the names of regions etc. I will begin with the function of prepositions and firstly with $\delta$ cá. $^{2}$ That the function of this preposition in the SP in most cases is related to the territorial issues has already been noted. ${ }^{3}$ For the purpose of the present study, this matter is further elaborated.

An important feature of the SP is that the roads are given mostly between adjacent settlements. This is not only due to the geographical situation, but is also related to the fact that each road led only through the territories of the settlements that are associated with it. This can be inferred from the roads which include more settlement names, in addition to the origin and the destination. In such cases, the SP uses the preposition $\delta \iota^{\prime}$ + "settlement name" in the genitive case without article highlighting that the road passed through the land of another settlement. This information about territorial passes would not have been provided in a random manner, but might have been associated with crossing borders. ${ }^{5}$ Though I cannot completely reject the suggestion that this information might have been given because there were other routes or because those roads were (re)built by Claudius, ${ }^{6}$ I believe rather that the information actually points towards the territories of autonomous settlements. ${ }^{7}$ This situation might help us, if only partially, in determining the territories of

\footnotetext{
${ }^{1}$ Lex. Corn. Schrev., p. 51, s.v. Iter; Nov. Lex. Man., p. 455-456; s.v. Iter.

${ }^{2}$ For the use of $\delta$ tá see Harrison 1858, 187-192 (esp. 189-190) and 195; for its use in earlier sources, see Luraghi 2003, 168-187 and Luraghi 2012, 367-374.

${ }^{3}$ For general statements see Onur - Alkan 2011, 69; Şahin 2014, 25.

${ }^{4}$ Şahin mentions the situation for R 25, see Şahin - Adak 2007, 176; Şahin 2014, 211 and R 52 (Şahin $2014,332$.

${ }^{5}$ There were certain rules for the goods to pass through the customs and there were pass points for traders on the borders between cities, for more information see IKaunos pp. 214-215; Takmer 2007, 172 and 176.

${ }^{6}$ Salway 2007, 202: "More importantly, this information also no doubt served to distinguish, where alternative routes existed, which road had been (re)built by Claudius."

${ }^{7}$ Zimmermann $(1992,141)$ considers the existence of local demoi and local cult traditions in central Lycia a form of partial independence. For further information on status of settlements see Schuler 1998, 17-32 (polis), 41-45 (demos) ve 45-49 (peripolion).
} 
the settlements during the Claudian period and the course of the roads in the field. In the SP there are 8 examples of the use of $\delta$ iá, 5 for settlements, 3 in other cases.

\section{A. The use of $\delta$ iá for the settlements}

\section{Trimilinda}

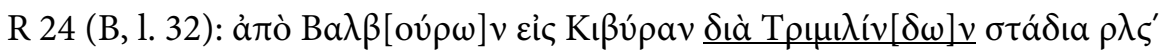

(The road) from Balboura (leading) to Kibyra (passing) through (the territory of) Trimilinda: 136 stadia.

Trimilinda was an autonomous settlement and the road did not pass through the centre of the settlement, but through its peripheral territory. This road must have passed through Dirmil/ Altınyay$1 a^{8}$, and this region was probably in the territory of a settlement called Trimilinda, from which the name Dirmil should have derived, at least by the time of Claudius. It is accepted by Kokkinia that the territory of Boubon extended at least $5-6 \mathrm{~km}$ to the east and southwest, and $7 \mathrm{~km}$ to northnorthwest. ${ }^{9}$ Bean reports a settlement $1,5 \mathrm{~km}$ east of Dirmil/Altınyayla and $6 \mathrm{~km}$ north of Balboura, $12 \mathrm{~km}$ east of Boubon, stating that it was a dependency of Balboura, not of Boubon, as is also accepted by Robert and Kokkinia. ${ }^{10}$ Two inscriptions on the road between Boubon and this settlement mention market inspectors (åyopavó $\mu \mathrm{ol}$ ) from Boubon, who fulfilled dedications to Ares as they had promised to their city. ${ }^{11}$ The evidence seems to suggest that the area where these two inscriptions were found and perhaps the ancient settlement near Dirmil might have been within the territory of Boubon. In the website of "Survey results in Boubon (Cibyratis, northern Lycia)" doubts are exposed that Dirmil/Altınyayla was in the territory of Boubon ${ }^{12}$, as is accepted by Coulton who placed Dirmil/Altınyayla the north-eastern points within the territory of Boubon. ${ }^{13}$ The ruins mentioned by Bean might have been Trimilinda. If not, then it means that there was another autonomous settlement named Trimilinda having territory around Dirmil as a region on the way from Balboura to Kibyra. Dirmil might indeed have been within the territory of Boubon, as Coulton suggests (see fn. 13), which might also cause to think that Trimilinda was perhaps Boubon. This could also be the possible explanation for the absence of Boubon, as one of the poleis of Lycia, which would otherwise be expected to have been listed. Such a case is probable only if Boubon was also called "Trimilinda" 14 at least by the time of Claudius (perhaps similar to the use Korykos instead of Olympos ${ }^{15}$ ). But apart from this evocative mention in the SP, unfortunately, there is no evidence to support such a hypothesis. Another possibility might be the settlement by the north-eastern shores

\footnotetext{
${ }^{8}$ Şahin - Adak 2007, 171-172; Şahin 2014, 203-204.

${ }^{9}$ Kokkinia 2008, 13.

${ }^{10}$ Bean 1971, 10; Robert 1983, 552; cf. Kokkinia 2008, 13.

${ }^{11}$ See now Kokkinia 2008a, 101-106 nos. 71-72.

${ }^{12}$ http://www.eie.gr/nhrf/institutes/igra/projects/boubon/territory.asp.

${ }^{13}$ Coulton 2012, 27 Fig. 2.11 and 30.

${ }^{14}$ Perhaps referring the earlier history of the city and region, cf. Şahin - Adak 2007, 171-172; Corsten Hülden 2012, 10; Corsten 2013, 80-82; Şahin 2014, 203-205.

${ }^{15}$ See Adak 2004.
} 
of Gölhisar Gölü. This settlement is identified as "Old-Kibyra", ${ }^{16}$ from where, according to the account of Strabo (13.4.17), the inhabitants were moved by the Pisidians, who settled there, to found Kibyra.

\section{Plata...}

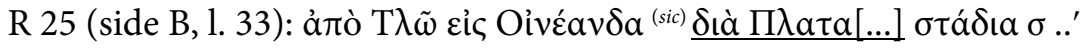

(The road) from Tlos (leading) to Oineanda (passing) through (the territory of) Plata...: 2.. stadia.

The suggestions for the restoration are $\Pi \lambda \alpha \tau \alpha[i ́ \alpha \varsigma,-\iota \tilde{\omega} v], \Pi \lambda \alpha \tau \alpha \dot{\alpha}[\nu \eta \varsigma,-v \tilde{\omega} v], \Pi \lambda \alpha \tau \alpha[\sigma \eta \varsigma,-\sigma \omega v] .{ }^{17}$ Rousset conjectures the restoration of $\delta i \grave{\alpha} \pi \lambda \alpha \tau \alpha[i ́ a \varsigma]=\delta i \grave{\alpha} \pi \lambda \alpha \tau \varepsilon[i ́ a \varsigma]$ as well, in the meaning of "par la grand-route", which seems unlikely in terms of its usage with $\delta$ tá. $^{18}$ The term plateia referred primarily to (broad) streets inside cities, not to tracks or roads through the countryside. It was a settlement between Tlos and Oinoanda, perhaps the ruins of Köristan/Dikmen or those of Çökek belonged to this settlement. ${ }^{19}$ The Hellenistic inscription on the boundary issues between Tlos and Termessos at Oinoanda mentions a mount called Masa, as the key point to be shared between the two parties. ${ }^{20}$ This mount is also attested in a treaty of 46 B.C. between Caesar and the Lycian confederacy associated with the borders. ${ }^{21} \mathrm{~A}$ wider field examination, particularly on the area between Köristan/Dikmen Tepe and north of Çökek, is certainly required to understand if this same vicinity is meant by Plata... and Masa, since Plata... seems by the early imperial period to be an autonomous settlement, located between the borders of Tlos and Oinoanda, while Mount Masa was at the border during the Hellenistic era. ${ }^{22}$

\section{Kollyba}

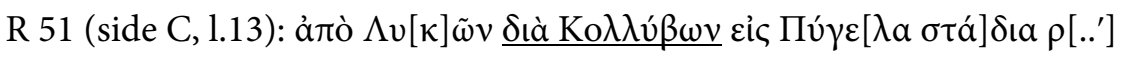

(The road) from Lykai (passing) through (the territory of) Kollyba (leading) to Pygela: 1.. stadia.

Since the village of Gödene (Altınyaka) has no remarkable ancient remains, the ruins at Bozbelen 3 $\mathrm{km}$ to the north of Gödene has been suggested as Kollyba. ${ }^{23}$

${ }^{16}$ Corsten - Hülden 2012, 37-38, for more archaeologic and epigraphic evidence from the site see pages 19-41.

${ }^{17}$ Şahin - Adak 2007, 176; Şahin 2014, 210.

${ }^{18}$ Rousset 2010, 142; cf. Şahin 2014, 211.

${ }^{19}$ Şahin - Adak 2007, 177-179; Şahin 2014, 212-215; For the remains of road between these two places see Yllmaz - Çevik 1996, 193; Korkut 2014, 506-510; Korkut 2015, 176-188; Çevik 2015, 260.

${ }^{20}$ For a detailed account on Mount Masa see Rousset 2010, 43-61 and 123-126.

${ }^{21}$ Mitchell $(2005,215-216)$ proposed that it should be identified somewhere in the section between the south of Oinoanda and the west (the author inadvertently employed "east”) of Girdev, cf. Rousset 2010, 123.

22 The Hellenistic inscription mentioned above (Rousset 2010) records a demarcation on Mount Masa. In our field surveys of 2015, we found some boundary markers in two groups, one consisting of three letters carved into the bedrock, an individual letter employed as a marker, just to the east of Köristan, the other group consisting of two markers carved into the bedrock, which are on the northern peaks above Tezli Dere. But unfortunately, they are insufficient to identify them with the boundary marks mentioned in the inscription and thereby to clarify the geography of Mount Masa.

${ }^{23}$ Şahin 2014, 330-331. 


\section{Kandyba}

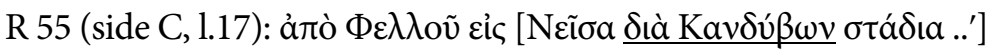

(The road) from Phellos (leading) to Neisa (passing) through (the territory of) Kandyba: .. stadia.

Kandyba has been localized to Çataloluk, between Dereköy near Phellos and Sütleğen near Neisa. Considering that the destination has been restored, it seems possible that another settlement might have also been recorded here, perhaps even the port of Antiphellos (see below pp. 106-108).

5. Rhodiapolis and Madamyssos

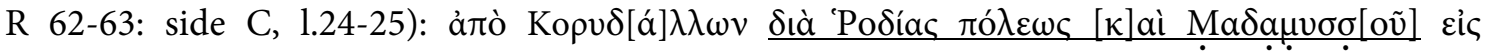

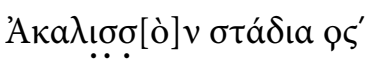

(The road) from Korydalla (passing) through (the territories of) Rhodiapolis and Madamyssos (leading) to Akalissos: 96 stadia.

Madamyssos has been localized at Baysı Village ca. 7-8 km north of Rhodiapolis. ${ }^{24}$ But this road between Korydalla and Akalissos is inconceivably divided into two routes by the editor princeps. ${ }^{25}$ This is a single road starting from Korydalla and ending in Akalissos, as also implied by Rinner, ${ }^{26}$ which passed through the peripheral territories of Rhodiapolis and Madamyssos, without entering these settlements. Even if the statement is to be divided, it would end up not with two routes but with three: 1. Korydalla - Rhodiapolis, 2. Rhodiapolis - Madamyssos, 3. Madamyssos - Akalissos. We would then have to divide all the other roads with Siá into two as well. If the roads had entered into the settlements prepositioned with $\delta$ iá, they would not have been shown in the middle of the course of the road but as the destinations. For instance, there would not be a single statement for the road between Korydalla and Akalissos, but instead we would probably have seen lines like follo-

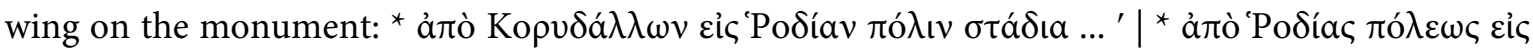

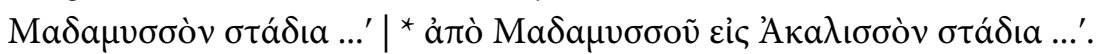

\section{B. The other cases prepositioned with $\delta$ เá}

\section{6. "plain"}

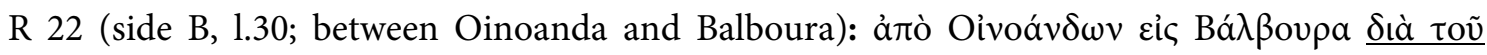

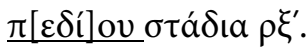

(The road) from Oinoanda to Balboura through the plain: 160 stadia

\section{7. "mountain country"}

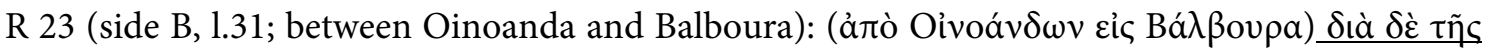

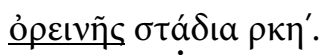

(The road) from Oinoanda to Balboura through the mountain country: 128 stadia

\section{Masikytos}

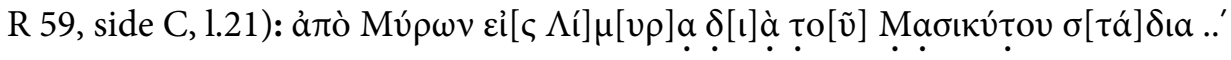

(The road) from Myra to Limyra over the (mountain of) Masikytos: ... stadia

\footnotetext{
${ }^{24}$ Şahin 2014, 396-397; see also below fn. 67.

${ }^{25}$ Şahin - Adak, 2007, 41 and 270-272 (STR 62-63); Şahin 2013, 47 and 394-397 (GZR 62-63).

${ }^{26}$ Rinner 2009b, 222 with Map VIII.4 and 224-225 with Map VIII.5.
} 
The nature of the Masikytos in this part could not be fully identified. ${ }^{27}$ I think that it cannot be a name for a settlement and should be either the name of the mountain or of a part of it. If it is the

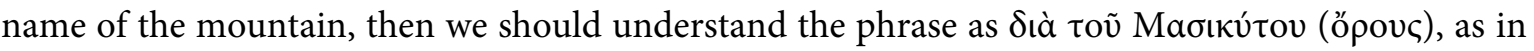

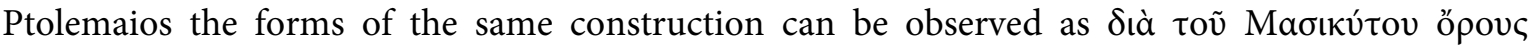

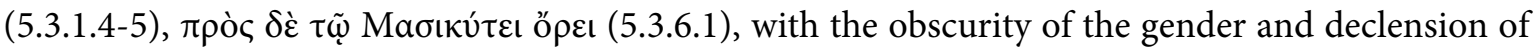
Masikytos. The reason for the use of Masikytos only for this road in the SP might be that this road, unlike the others, was constructed to a height of $900 \mathrm{~m}$ above sea level with many zigzags as a major work ${ }^{28}$ or, that in antiquity the name of Masikytos was actually used only for a certain section at the south of the Beydağları mountain range ${ }^{29}$. In this section, there was probably either a very poor connection or there was none. This is the very place where the Lycians expressed their gratitude for the Roman construction of the road through the erection of the Claudian monument on Bonda. ${ }^{30}$

These examples clearly show the difference in the use of the articles, which can also be supported by

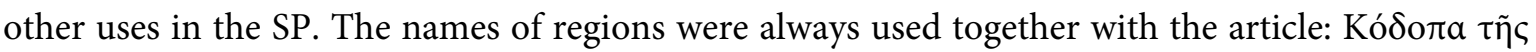

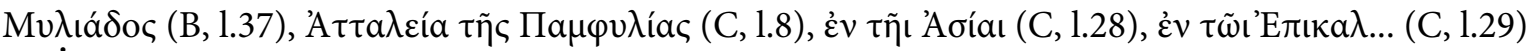

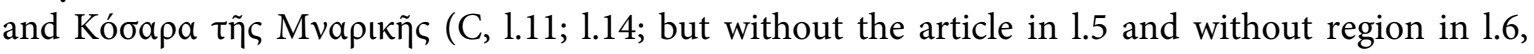
probably due to the concern to fit the lines into the space). Another epigraphic example of this kind of use can be observed in a decree regulating the transportation issues from Myra to Limyra and the precautions against smuggling. ${ }^{31}$ A section of the inscription reads ... ảंò $\tau \tilde{\eta} \varsigma \Delta \alpha \sigma[\varepsilon \dot{i}] \alpha \varsigma \mu \eta \dot{\tau} \tau \varepsilon$ àmò

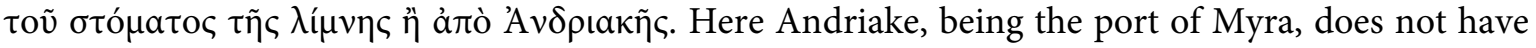

\footnotetext{
${ }^{27}$ Şahin questions that "through Masikytos" was used only for this road, since many roads in central and eastern Lycia also passed the Mount of Masikytos; he believes this name in the SP might have also belonged to a settlement homonymous with the mountain, referring to the example from Strabon who says ó Kpá

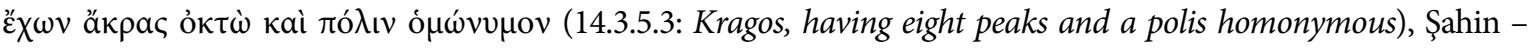
Adak 2007, 265; Şahin 2014, 383-384.

${ }^{28}$ See also Şahin - Adak 2007, 263; Şahin 2011, 55-56; Şahin 2014, 380; cf. Mittenhuber 2009b, 50.

${ }^{29}$ Masikytos may have described only this part of the mountain range. Cf. Wörrle in Marksteiner Wörrle 2002, 561; See sources and other details in Takmer 2002, 35-36. Plin. NH 5.100.4-6 (... nunc sunt montana Gagae, Corydalla, Rhodiopolis. iuxta mare Limyra cum amne, in quem Arycandus influit, mons Masicytus, Andria civitas, Myra, ...) points to its localization between Limyra and Myra. The settlements Ptolemaios (5.3.6) put around Masikytos are Korydalla, Sagalassos (taken as Akalissos), Rhodiapolis, Trebendai, Phellos, Myra and Limyra (cf. Şahin 2014, 100). Here Phellos is actually a bit far from Alacadağ. Sagalassos, considered as corrupted from Akalissos, might also be taken as Tragalassos, a settlement on Alacadağ see Alkan 2011, 101-105. Quintus Smyrnaeus mentions Masikytos as opposite Cape Gelidonya (3.234: vaĩ $\delta^{\prime}$ ö $\gamma^{\prime}$

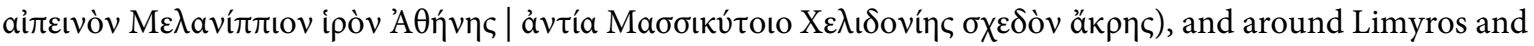

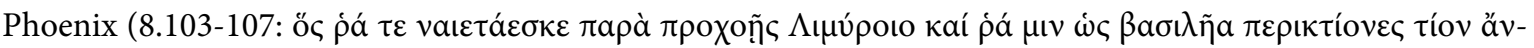

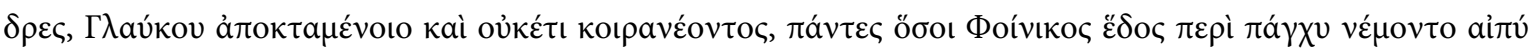

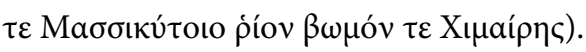

${ }^{30}$ For the details of the monument and its inscription see Marksteiner - Wörrle 2002; Marksteiner thinks that there was already a partial pre-Roman road connection in that area, but he emphasizes that the road on the western slope has an homogeneous character respresenting a complete new Claudian construction or a massive work of renovation (Marksteiner - Wörrle 2002, 553).

${ }^{31}$ LBW III $1311=$ OGIS 572 = CIG 4304a; for the content of the inscription see Robert 1963, 35-37; Robert 1966, 52; Zimmermann 1992, 233-235; Marksteiner - Wörrle 2002, 561; Takmer 2004, 112.
} 
an article, while Daseia and the "mouth of the lagoon" have one, so Daseia stood here as a natural formation or regional name, as was already concluded in a recent contribution ${ }^{32}$ based mainly upon the geographical features of the region.

Next, I shall briefly discuss the preposition ' $\varepsilon i \varsigma$ ', which not only precedes the destinations, but also

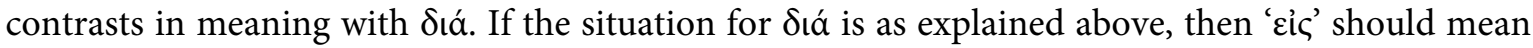
that the distance given for the roads were measured until the settlement itself, at least to the entrance gates or to a nearby the town-zone where usually the measurement and array of milestones started in conformity with Roman tradition. There are examples reflecting this situation. For instance, a Trajanic milestone in Cyrenaica in north Africa, erected as the first milestone on the road from Kyrene to Apollonia to the north, shows that the zero point of the distance is somewhere in the city centre, as $1 \mathrm{MP}$ (ca. $1480 \mathrm{~m}$ ) is the distance between the two points. This zero-point was also proved by a Hadrianic milestone (on which one reads 1 MP) on the road between Kyrene and Balagrae to the south. ${ }^{33}$ The Lincoln milestone (RIB 2241) in Britain is also considered as evidence that measurements were taken from town centres, though there are doubts as to whether it actually stood in its current place in antiquity. ${ }^{34}$ Rodwell, in the conclusion of the survey on the British section of the Antonine Itinerary, reported that the routes in the Antonine Itinerary started or ended in a point that was in or at the edge of the town-zones (of which the widths vary depending on the settlement and the epoch), not in the centre of the settlement. ${ }^{35} \mathrm{He}$ also states the following for the town-zones of the settlements in Britain (p. 98): “... it remains to consider the nature of the townzone itself. In the case of civitas - capitals and towns of lesser status only the immediate environs (principally cemeteries and probably extra-mural industrial areas) are included. Hence, it is simplest to regard the boundary revealed by the itinera as the junction between town lands (under civic control) and the countryside (composed of private farms and estates). The extent of the town-zone was clearly related to the size and status of the settlement which it surrounded ...". Rivet and Jackson believe that measurements should have started from city centres. ${ }^{36}$ As another example, the distances mentioned in the miliarium aureum (golden milestone), which was erected by Augustus in the Forum in Rome, started from the city gates in the direction of the destinations. ${ }^{37}$ Van Tilburg refers to a statement in Plin. NH 3.66 (... a miliario in capite Romani fori statuto ad singulas portas...) to support this view. ${ }^{38}$ Another miliarium (called milion), which had the same purpose, was constructed by Constantinus in Constantinople. ${ }^{39}$ The milestone found in the Church of St. Nicholas in $\mathrm{Myra}^{40}$ was probably moved from one of the roads ${ }^{41}$ and it might even have stood in a point, near to where the road to the west started. Furthermore, an unpublished Tetrarchic milestone from

\footnotetext{
32 Şahin 2011, 58; cf. Marksteiner - Wörrle 2002, 561.

${ }^{33}$ Goodchild 1950, 83-84 and Fig. 1.

${ }^{34}$ Rodwell 1975, 77 and 86-87.

${ }^{35}$ Rodwell 1975, 76-79 and 97-98.

${ }^{36}$ Rivet - Jackson 1970, 38-39.

${ }^{37}$ DRGA 762-763, s.v. Milliare; Platner 1929, 342, s.v. Milliarium Aureum.

${ }^{38}$ Van Tilburg 2007, 20.

${ }^{39}$ Cedr. 1.564; Suda mu.1065; Parastaseis 16.

40 Takmer 2004, 109.

${ }^{41}$ Şahin 2014, 118.
} 
Rhodiapolis stands in situ by the gate at the eastern exit of the city. Mittenhuber considered city gates as starting and ending points for the SP, but since the city gates of the settlements cannot be defined precisely, their team usually used agoras and sometimes theatres or even a general point depending on the definability of the settlement, as benchmarks in the measurement between settlements on the GIS. ${ }^{42}$ A recent survey on the road between Xanthos and Neisa in the SP showed that measurements seems to have been between the borders of town-zones ${ }^{43}$, instead of the very centre of the settlement, similar to Rodwell's conclusion above.

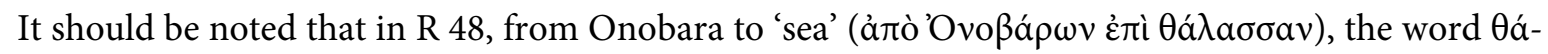
$\lambda \alpha \sigma \sigma \alpha$ was not preceded by the article and $\varepsilon i \varsigma$, the very first meaning of which is "to; into; within" 44 , but only by $\dot{\varepsilon} \pi$ í meaning "upon, on to; to; up to, as far as; towards" with the accusative case in motional use. ${ }^{45}$ The absence of an article could have meant that $\theta$ á $\lambda \alpha \sigma \sigma \alpha$ was actually a place name,

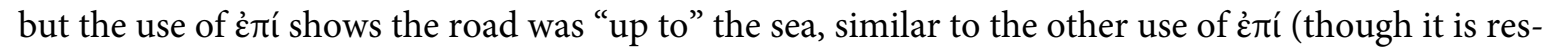
tored by the editor) in $\mathrm{R} 42$, that limits the road construction to 32 stadia between Idebessos and Kitanaura of the Termessians. If $\theta a ́ \lambda \alpha \sigma \sigma \alpha$ had been the name of a settlement or of a port, it would

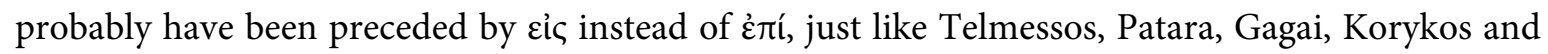
maybe Kalabatia (see below pp. 106-109). Then we would expect that it was autonomous. The commonness of the use without article can be seen from a search in the TLG database that provides a

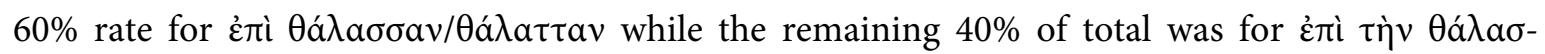
$\sigma \alpha v / \theta a ́ \lambda \alpha \tau \tau \alpha v$. Şahin tends not to accept that $\theta a ́ \lambda \alpha \sigma \sigma \alpha$ was a harbour settlement due to the difficulties in locating certain territorial and geographical areas around the shores near Onobara. ${ }^{46}$ There was therefore, perhaps a connection to another road on the coast, ${ }^{47}$ e. g. from Phaselis to Attaleia.

The semantic difference in the use of eis (for ports/harbours) and غ̇ $\pi$ í (for landmarks) in ancient Greek periploi (maritime itineraries) can also be observed. For example, a part from the Lycian section of the SMM (235-238) reads:

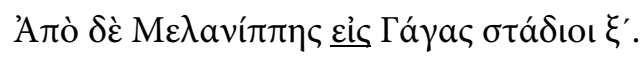

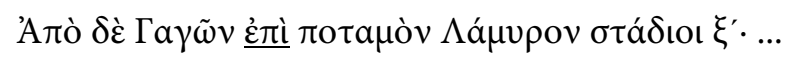

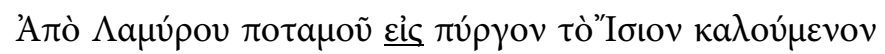
$\sigma \tau \alpha^{\prime} \delta \iota \mathrm{lo} \xi^{\prime}$.

'A
From Melanippe (in)to Gagai 60 stadia.

From Gagai till River Limyros 60 stadia...

From Limyros River (in)to the tower called Ision 60 stadia.

From Ision tower (in)to Andriake 60 stadia.

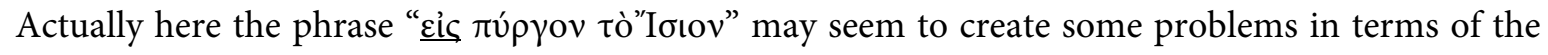
arguments presented, namely how a ship can enter into a tower. But this may mean a harbour with a lighthouse marker-tower or protected by a tower by the sea. Based on the SMM, the Hellenistic tower at Yukarı Beymelek was suggested for the localization of the Ision tower. ${ }^{48}$ This suggestion

\footnotetext{
${ }^{42}$ Mittenhuber 2009c, 102-103.

${ }^{43}$ Onur 2016, 215.

${ }^{44}$ For the use of घic see Harrison 1858, 209-212; for the earlier use, see Luraghi 2003, 107-117.

${ }^{45}$ For this meaning of $\dot{\varepsilon} \pi$ í with the accusative see Harrison 1858, 296-299; for the earlier usage Luraghi 2003, 305-308.

${ }^{46}$ Şahin - Adak 2007, 237-238; Şahin 2014, 320-321.

${ }^{47}$ Şahin - Adak 2007, 237-238; Salway 2007, 200; Şahin 2009, 104 fn. 14; Şahin 2014, 321.

${ }^{48}$ McNicoll - Winikoff 1983, 320-321.
} 
was received with scepticism, due to the tower's situation, which was too far from the sea to be a station in a maritime itinerary. ${ }^{49}$ The recent suggestion that Ision Tower may be sought in Gök Burnu has problems in terms of distances, though the distance in the SMM is considered an exaggeration. ${ }^{50}$ The distance in the SMM from Limyros Potamos to the Ision Tower is 60 stadia, namely ca. 11-12 km, but the distance from Limyros to Gök Burnu is ca. $5 \mathrm{~km}$. Even if it is accepted, then another problem occurs. The distance between Gök Burnu and Andriake is not less than $20 \mathrm{~km}$, while the distance between the Ision Tower and Andriake, according to the SMM, is 60 stadia (ca.11-12

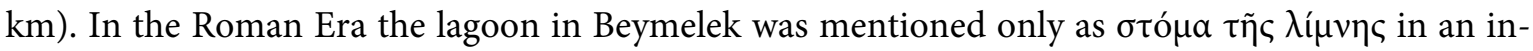
scription (see references in above fn. 31), and it may have been named Symbolon in the life of Saint Nicholas of Sion in the $6^{\text {th }}$ century A.D. ${ }^{51}$ But if in earlier times the port in Beymelek (by the lagoon) was called "Ision Tower" perhaps after the Hellenistic tower at Yukarı Beymelek or from a tower that formerly marked the entrance to, or stood beside the lagoon, this localisation conforms with both the distance and the sense of gis in the SMM.

\section{The Distances and Settlements}

It is accepted that the list given in the SP does not serve any practical use for journeying. ${ }^{52}$ Since the SP is to be taken as an official report of the measurement of the roads, it must be expected that the information on it is accurate. ${ }^{53}$ The SP gives a list of roads and their lengths, but the sum of these distances does not represent the total length of the entire construction since the roads coincide in many places. ${ }^{54}$ We cannot deduce the length of the entire road-system, if we disregard the slim possibility that this total distance was inscribed on one of the lost blocks as yet undiscovered. We should expect the individual road lengths given in the inscription to be accurate, since the preface of the road list specifically draws attention to the question of measurement at the top of side B: ...

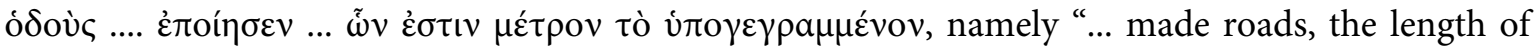
which has been written below...". Salway tries to find another sense than that which the SP recorded and re-constructed 30 routes (itinera) from this road list on the monument. ${ }^{55}$ The verb $\pi$ roté $\omega$ used for ódov́c presents us with a generalized meaning. However, we can see, that this subsumed the

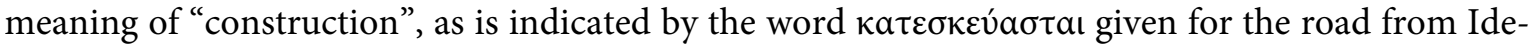

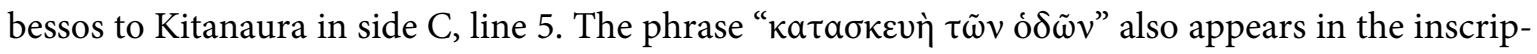

${ }^{49}$ Zimmermann 1992, 99 fn. 187; Hellenkemper - Hild, 2004, 573, s.v. Ision Pyrgos; Çevik - PimouguetPédarros 2010, 267.

${ }^{50}$ Şahin 2014, 380.

${ }^{51}$ Alkan 2011, 107-108; Alkan 2013, 89-97.

${ }^{52}$ Şahin - Adak 2007, 14; Rinner (2009b, 212, 243, 248-249) emphasizes the absence of connections between some places, e. g. Lesei... and Idebessos, and this makes the SP unsuitable as an itinerary for planning a journey; Şahin 2014, 19; cf. Işı1k - İşkan - Çevik 2001, 30.

${ }^{53}$ Mittenhuber 2009a, 7.

${ }^{54}$ For example, there are roads to Tlos from Xanthos, Pinara, Kadyanda and Araxa. They are not independent of each other. The roads should have joined somewhere near the Xanthos River, then leading to Tlos in a single road (Şahin 2014, 25); For the intersections in the Xanthos Valley see Rinner 2009a and Rinner 2009b, 226-227 and Map VIII.6.

${ }^{55}$ Salway 2007, 198-199 Table 1; Salway 2012, 207-208. 
tion of the Claudian monument on Bonda Tepe. ${ }^{56}$ So roads were constructed. ${ }^{57}$ Biagi believes that Claudius did not actually construct the roads at all, but created a network, which was incorporated into the cursus publicus and represented Roman sovereignty by listing the lengths of roads between settlements. ${ }^{58}$ Biagi is right in highlighting the work of measurement. But her work omits certain sources and the latest developments in the history and geography of Lycia. Since she did not have the opportunity to consult Şahin - Adak 2007 (see Biagi's fn.1: "non vidi”), this has also led to certain omissions. The part of the "nouvelle province de Lycie-Pamphylie" of the title of her contribution shows that she still holds to the old communis opinio about the double province, but the Stadiasmus itself directly shows that the new province contained only Lycia. While she interprets the

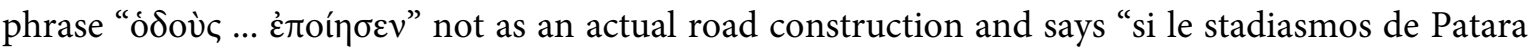
claironne la «construction» des voies par Claude, c'est dans le sens de l'appropriation par le pouvoir romain d'un certain nombre de voies, de l' organisation romaine du réseau, et ce dès l' incorpora-

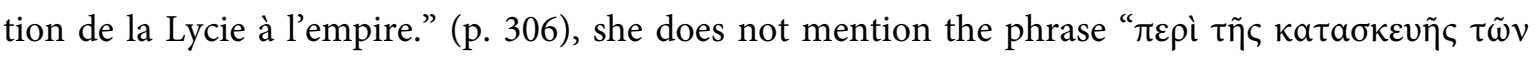
ó $\tilde{\omega} v$ " in the Claudian monument of Bonda (see fn. 30), that shows there was also actual road construction or major restoration. ${ }^{59}$ Polla and Rinner also concluded that not all the roads were newly constructed.$^{60}$ Lebreton rightly argues that the road construction for the whole country could not have been completed within the period between the annexation in 43 A.D. and the erection of the SP in 46 A.D. ${ }^{61}$ Rousset considers that even without actual construction, the measurement of the roads was sufficient to symbolize Roman power and annexation, and that the list in the SP was actually based upon the existing Lycian road network, and includes development, rehabilitation and construction. ${ }^{62}$ The construction of some roads originally for military requirements ${ }^{63}$ during the annexation may be observable on some important routes, such as Tlos - Kastabara - Choma and Xanthos - Neisa - Choma (both reaching to the Mylias), and Myra - Limyra. These roads were constructed on a shallow incline and were wide enough for carts, notably in the steep sections. ${ }^{64}$

The roads in the SP have almost exact distances, for which there need to be defined places or points to begin and to end (see the discussion above pp. 95-96 on eis). It should also be noted that almost

\footnotetext{
${ }^{56}$ There are numerous inscriptions mentioning road construction. For example, various epigraphic examples on milestones from Thyateira reflect road works with different verbs to describe what was done. Пoı́ $\omega$

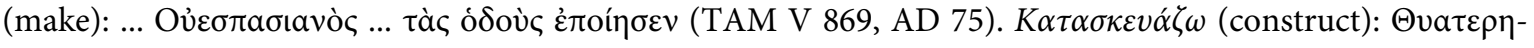

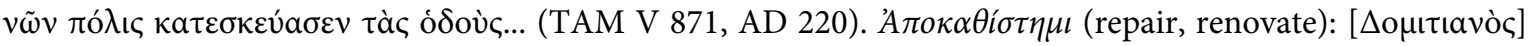

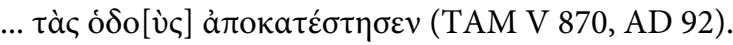

${ }^{57}$ Polla - Rinner 2009, 85-86; Şahin 2014, 23, 25, 111; Iş1k - İşkan - Çevik 2001, 28-29 and 50.

${ }^{58}$ Biagi 2008, 306-307.

${ }^{59}$ Marksteiner - Wörrle 2002, 553 and $561 \mathrm{fn} .58$.

${ }^{60}$ Polla - Rinner 2009, 85-86.

${ }^{61}$ Lebreton 2010, 67-74.

${ }^{62}$ Rousset 2013, 68-70.

${ }^{63}$ Şahin - Adak 2007, 17; Şahin 2009, 104-105 (for the road from Sidyma to [Kalabatia]); Şahin 2014, 16.

${ }^{64}$ The massive road construction in the steep slopes to the east of Tlos have been investigated by our field survey team, see the relevant report in Akyürek Şahin et al. 2016; The mountainous road from Xanthos to Neisa has recently been investigated, see the second article by the author in this volume; for the road between Myra and Limyra see Marksteiner - Wörrle 2002, Şahin 2011 and Şahin 2014, 379-387.
} 
all of the surviving numbers of lengths recorded are divisible by eight as integers, as a stadion is one eighth of a Roman mile, including the length of the road from Pinara to Telmessos, which is corrected by the editor from 177 on the stone to $176^{65}$. Two examples, if divided by eight, do not give integers, but can be resolved into half miles. These are the roads from Tlos to Telmessos $(188 / 8=$ 23,5 MP) and from Kadyanda to Araksa $(108 / 8=13,5 \mathrm{MP})$. So even though the actual measurements were completed for each road, the actual lengths recorded were then rounded to form integers or halves, as the Roman surveyors worked in whole or and half miles ${ }^{66}$. Accordingly, the distances recorded in the list might be a little more, or a little less, than the actual length of the road itself, given that the recorded distance has been either rounded up or down. Şahin's proposal on this matter is that measuring did not start or end always in the settlements, but measuring points might have been in some cases the mansiones, which would be aligned with the settlements, on the main roads. ${ }^{67}$ This can be applied for some sources, like e.g. Tabula Peutingeriana.

However, while it is certain that there were secondary roads extending from the main roads to the settlements, I think that it is more difficult to prove this for the SP than to suppose that the distances were actually indicative of a measurement between the settlements themselves. What I actually understand from the statements of the SP is more precise. For instance, when the SP says átio

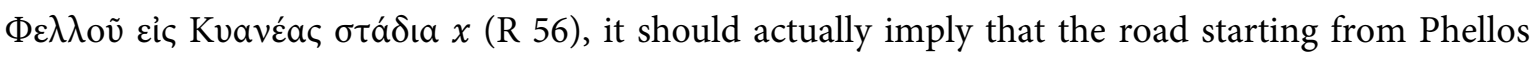
will end in Kyaneai after $x$ stadia, not at a point outside the city, such as in a plain. ${ }^{68}$ This suggested practice, which does not seem to fit with the purpose of the SP, would have the result that all the distances given positively on the monument are unverifiable. I will try to explain this through using the same examples, namely the roads between Phellos, Kyaneai and Myra (RTs 56-57).

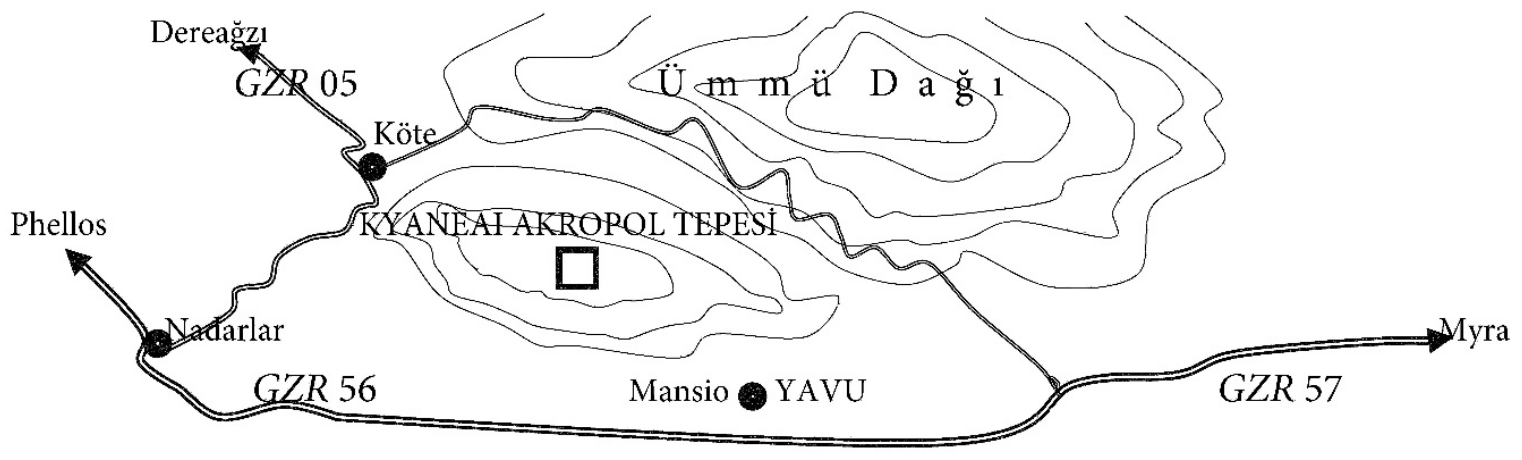

Fig. 1) The road network around Kyaneai according to Şahin (2014, 123).

There were probably two roads to Kyaneai near the place called Nadarlar, to where R 56 came in a single road from Phellos. The transit road, that is also a main road, leads through the Yavu plain to the south of Kyaneai. But the statement in the SP "from Phellos to Kyaneai" cannot be applied to this transit road, since it does not lead to Kyaneai but somewhere in the plain in its close territory.

\footnotetext{
${ }^{65}$ Şahin 2014, 146.

${ }^{66}$ Salway 2007, 202.

${ }^{67}$ On this point see Şahin 2014, 123, although Şahin modifies this position in a later version of the text, which concerns the road between Korydalla and Akalissos (p. 395; cf. also p. 25).

${ }^{68}$ This was suggested by Şahin $(2014,123)$ discussing the same route. But I noted my reluctance in Onur Oktan 2013, 98 fn. 10, believing it required further study.
} 
Although there is a shortcut that connected the road on plain and city centre, climbing up to the southern necropolis of Kyaneai, and Kolb emphasizes its importance in the Classical period, ${ }^{69}$ the main access to the city in the imperial period should have been from its northern and eastern sides. There was certainly a road through the Yavu plain, but this was not for those who came from west and went to Kyaneai. The road measured in the SP was probably the modern secondary road, on which the remains of the old road can still be seen near Köte. Traces of a shorter road are also still visible amongst several rock cut tombs between Kyaneai and Nadarlar, starting 60-70 m east of the theatre of Kyaneai. Similarly, the measurement from Kyaneai and Myra should have started from the eastern exit of Kyaneai, where there is a well preserved Roman road amongst the Roman sarcophagi and probably provided the most comfortable access to Kyaneai from the east. ${ }^{70}$ This resembles the case of the road from Patara to Phellos on the mountain (R 54). ${ }^{71}$ If the road between Phellos and Kyaneai had passed through the plain south of the latter polis, Kyaneai would not have been mentioned as the destination in R 56 but $\delta$ á would have been employed to state that the road passed through the peripheral territory of Kyaneai, with Myra as the destination. There is a similar situation on the road between Korydalla and Akalissos mentioned above (see p. 93, no. 5). In terms of geography, this road must obviously have passed through the Alakır Valley in a place close to Rhodiapolis. According to the theory of mansiones, we should have had a road from Korydalla to Rhodiapolis (see above p. 93) represented by a mansio on the main road. But this is not the case. The SP gives no information about any road from Korydalla to Rhodiapolis. Furthermore, I think it is unlikely that the measurement in Rs 56-57 was carried out through the Yavu plain for the benefit of those who wished to go to Myra without going into Kyaneai, because the list did not serve as an itinerary, but was a presentation of the inventory of the roads measured and built/renovated if necessary (see above p. 97), in the form of a public notice, e. g. a $\gamma \nu \tilde{\omega} \sigma ı /$ /notitia. In other words, the SP merely records the roads and their measurements and is not intended as a guide for travellers.

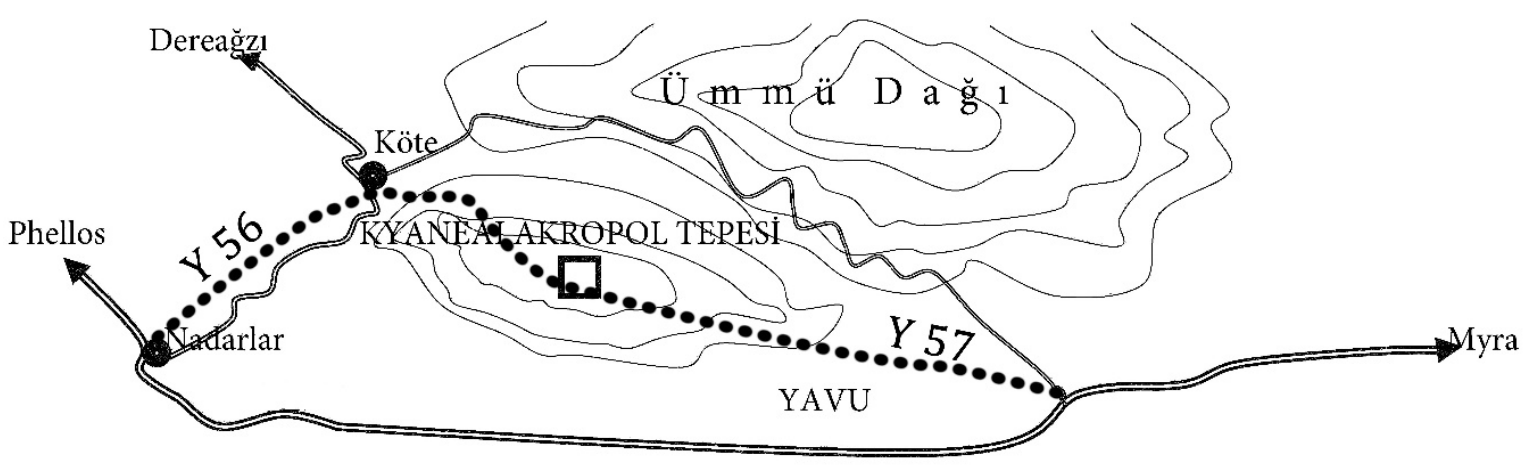

Fig. 2) The schematical courses of the roads around Kyaneai (modified from the plan in Fig. 1)

We had reported that Schuler, who accepts that Köybaşı lay within the territory of Patara, ${ }^{72}$ is wrong to state that if the ancient road from Xanthos to Neisa passed through the Alacaışı pass by Köybaşı, then the affiliation of Köybaşı cannot be with Patara, since this road should have led only

\footnotetext{
${ }^{69}$ Kolb 1995, 247.

${ }^{70}$ Kolb 1995, 247; Kolb 2008, 185; Hülden 2010, 185-186; Onur - Oktan 2013, 100.

${ }^{71}$ For the details of R 54 see Onur - Alkan 2011.

${ }^{72}$ Schuler 2010, 81.
} 
through the territories of Xanthos and Neisa. ${ }^{73}$ But accepting that the road between Xanthos and Neisa passed through the Alacasşı pass raises other questions, especially regarding the modern distance, which exceeds the distance recorded in the SP by about $10 \mathrm{~km} .{ }^{74}$

\section{The Status and Territories of the Settlements}

Before proceeding to the status of settlements mentioned in the SP, it is useful to mention the relationship between the regions of Oktapolis, Mnara and Mylias in Lycia, and Pamphylia and Asia outside Lycia and some of the settlements named in the SP. It has been suggested that this practice was intended to prevent confusion with other homonymous settlements. ${ }^{75}$ But I do not think such a confusion would really be possible, since the list already claims that roads were constructed $\kappa a \theta^{\prime}$ ö $\lambda \eta v \Lambda v \kappa i ́ a v$, and no one would really suspect that Kodopa, for example, which was positioned on a road from Khoma leading to Akarassos, could be other than the Lycian Kodopa. The association of Kodopa with Mylias might mean that the road network reached Mylias by the road from Khoma to Kodopa. In the following road, Kodopa is given by itself. Next, the same applies for the road from Kalynda to Lyrnas, the latter tied with Oktapolis. Again in the following road, Lyrnas is given alone. The case of Kosara with Mnarike - possessive (ktetikon) form from Mnara ${ }^{76}$ - is more complicated. Kosara is first mentioned after the road from Idebessos to Kitanaura of the Termessians (see p. 102), and it is associated with Mnarike. On the following road Kosara is named on its own. Then after the road from Onobara to the "sea", the SP returns to the region of Mnarike, which is given again with Kosara's second occurrence. In the same manner, Kosara's third occurrence on face C 1 . 14 is after Pygela, which was probably not in Mnarike. The SP again supplies the information that Mnarike was attached to Kosara, perhaps because the road network of the SP is back in Mnarike. However, I cannot say that this was the intention of the SP, and it seems that this case remains obscure, until it is clarified by new evidence. The case of Attaleia which was associated with Pamphyl-

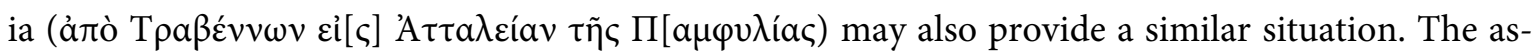
sociation of Kibyra with Asia is given in a different form and context, which should be connected with the unknown changes made by Quintus Veranius on the boundary between Lycia and Asia (C

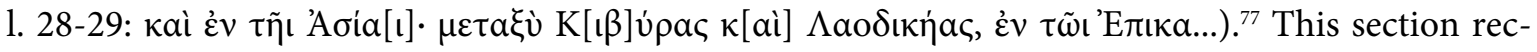
ords some activity between Kibyra and Laodikeia, which cannot be clearly defined due to the illegibility of the relevant section of the inscription.

\section{A. The Cities outside Lycia in the SP}

Four cities lying beyond the borders of Lycia are recorded in the SP, although one of them (Kaunos) is dubious. Two of these were recorded without affiliation: Kaunos and Termessos, in the lat-

\footnotetext{
${ }^{73}$ Şahin 2010a, 141-144; Onur - Alkan 2011, 67 with fn. 5. and 69.

${ }^{74}$ A subject that has been investigated by the author, see in this volume Onur 2016.

${ }^{75}$ Şahin 2014, 174 and fn. 255 (for Lyrnai of Oktapolis); 223 (for Kodopa of Mylias); cf. Salway 2007, 203 and Rousset 2013, 72. It is implied that the regional information of Kodopa (in Mylias) was given to describe the settlement geographically in the correct region (Şahin 2014, 223). A homonymous settlement in Kilikia was shown as an example (Şahin 2014, 229 and fn. 462c).

${ }^{76}$ For Mnara see Tüner 2002, 68-70.

${ }^{77}$ For more on the matter see Şahin - Adak 2007, 290-294; Şahin 2014, 422-428.
} 
ter case taking the form of the reference to Kitanaura as a settlement or colony belonging to Termessos; the other two are Kibyra in Asia and Attaleia in Pamphylia.

For the case of Termessos, the section C 1.3-9 is as follows:

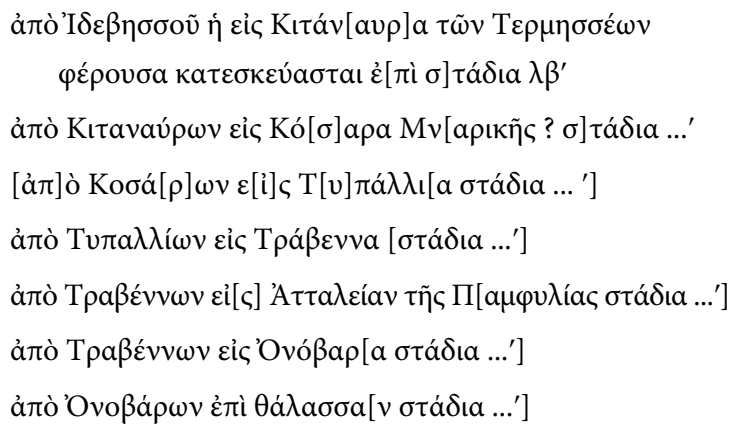

What we can directly deduce from this section is that Kitanaura in 1. 3-4 belonged to the Termessians (not a regional attribution like the others, but an ethnicon) by the time of the SP, while the other mentions of Kitanaura ( 1.5 and 1.12 on Face $\mathrm{C}$ ) do not mention Termessos. But I think it is not so easy to conclude that the places located to the north of Kitanaura also belonged to the Termessians. ${ }^{78}$ Kitanaura might have been a detached colony in the south, similar to the settlement of the Termessians at Oinoanda ${ }^{79}$. Most of the area between Termessos in Pisidia, Oinoanda and Kitanaura might have belonged to the Termessians ${ }^{80}$, and perhaps to Isinda (near Korkuteli), whose political status is not clear by the reign of Claudius, provided that Termessos/Oinoanda remained in Lycia in the imperial period. However, Kosara, Typallia, Trebenna and Onobara should have been out of the Termessian zone by the time of the SP, since this is contrary to the claim of the SP that Clau-

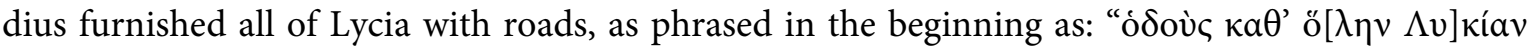

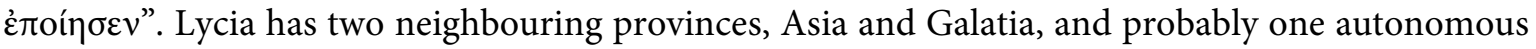
power - Termessos. The representation of Kitanaura as belonging to the Termessians in the SP in-

${ }^{78}$ Şahin - Adak 2007, 218, 230-232; Şahin 2014, 297, 313-314.

${ }^{79}$ According to Coulton $(1982,127-129)$, there were two communities sharing the public affairs in one city. The Oinoandeans dealt with the buildings and cemeteries while the Termessians at Oinoanda, the full official title of the citizen body defining themselves as the successors of the colonists from Termessos in Pisidia, were responsible for honorific statues, official correspondence and coinage. The city of Oinoanda, beside Oinoandans, contained a distinct community of Termessians (cf. Wörrle 1988, 45-53; Milner - Eilers 1995, 85; Milner - Eilers 2006, 66); But Rousset (2010, 87-88) finds improbable to consider Termessians near Oinoanda and Oinoandeans as two different communities, indicating that Oinoanda appears as a name of region near Termessians inhabited İncealiler, not as a city, in the earliest sources and that the city of Termessians near Oinoanda was the ruins above İncealiler; In his recent contribution, Gander (2014, 393-402) expresses that Oinoanda was a name already existed in the region, but not for a city, prior to the arrival of Termessians, also emphasizing the absence of archaeological material dating before late $3^{\text {rd }} /$ early $2^{\text {nd }}$ century amongst the ruins in İncealiler. Then he proposes that the region around Ören, where the city of Araxa was localized, was probably Wiyanawanda (Hit.)/Winbēte (Lyk.)/Oinoanda, which might have been re-named as Araxa with the Persian period.

${ }^{80}$ On the territory of Termessos see Heberdey 1929, 5-15; Heberdey 1934, 734-737; Çelgin 2009, 102-103; İplikçioğlu 1999; İplikçioğlu 2004; Porcher 2009; Hellenkemper - Hild 2004, II, 878; Çelgin 2013, 115-116 and fns. 1-2. 
dicates the autonomy of the latter, recognized both by Roman authorities and the Lycians during the reign of Claudius. ${ }^{81}$ Otherwise Kitanaura would not have been shown as attached to Termessos. If Kosara, Typallia, Trebenna and Onobara were in Termessian territory, it would mean that the Lycian network listed in the SP first entered the area controlled by Termessos, before it was connected to Galatia through the road leading to Attaleia of Pamphylia.

In the cases of Kaunos (see below), Kibyra, ${ }^{82}$ and Attaleia in the SP, the road network does not continue once it passes beyond the border of Lycia and the road network does not lead to another provincial or municipal territory (but see above p. 101 for the explanation for the mention of Laodikeia in the SP). Furthermore, Kibyra, Attaleia and perhaps Kaunos were already under Roman dominion, while Kitanaura belonged to the Termessians. Perhaps Kitanaura was the easternmost settlement at the very edge of the Termessian zone in the region, after which there were no further lands belonging to Termessos. The territory of Termessos was probably the reason why no connection was given between Akarassos or Soklai in Milyas of Lycia and Trebenna in the SP, despite the existence of fortresses such as Gilevgi and Ovacik, ${ }^{83}$ indicating the existence of important roads. A Claudian inscription found in Müğren (close to Gilevgi and Ovacık) showed that there was a frontier

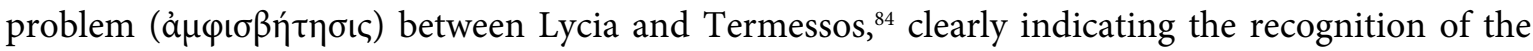
autonomy of Termessos both by the Lycians and Romans. Şahin, comparing the phrases of $\pi \varepsilon \rho i ̀ \tau \tilde{~} \varsigma$

${ }^{81}$ Termessos ensured its independence, which it lost during First Mithridatic War (89-85 B.C.), in 72 (or 68) B.C. with Lex Antonia de Termessibus (CIL 12 2 2, 589). For details see Mattingly 1997, and also Arslan 2007, 184 and fns. 835-836; 254-255. Nolle $(1996,25)$ thinks that Kitanaura, which he localizes in Sarayclk, came under the rule of Termessos by that time, after the campaigns of Isauricus, cf. İplikçioğlu 1999, 310. The coins issued by Termessos from several periods also show their autonomy, as they do not have the image of the emperors, but their local god Zeus Solymeus, see SNGBN 2184 (A.D. 41-96), SNGBN 2146 (A.D. 1-200). Termessos also had coins with the legend of AYTONOM $\Omega N$ in a later period, see for example BMC 39 (A.D. c. 150-250), BMC 54 (A.D. c. 238-268). An inscription of the $3^{\text {rd }}$ century A.D. from the theatre of Termessos

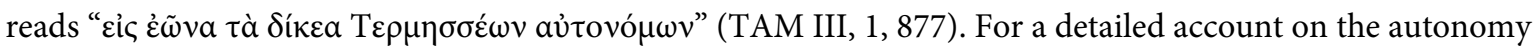
of Termessos see also Mitchell 1995, 102-103.

Çevik and Pimouguet-Pédarros think that the Heroon in Kitanaura dates to a time between the $1^{\text {st }}$ century B.C. and the $1^{\text {st }}$ century A.D. They report that the political status of the city is not clear at the time when the

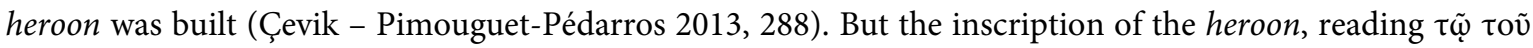

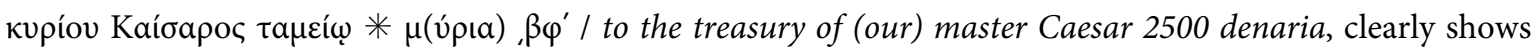
that it was constructed at a time when Kitanaura was in fact under Roman jurisdiction. So the heroon cannot be dated to before the middle of the $1^{\text {st }}$ century A.D., since the SP gives the latest attestation as to when Kitanaura was within Termessian land.

${ }^{82}$ Kibyra remained in Asia during the organization of the provincia Lycia, see the arguments for the city's association with the province of Asia in Corsten 2007, 179-181; cf. Rousset 2010, 109.

${ }^{83}$ See Harrison 2001, 54-60; Porcher (2009, 290-296) defines Ovackk as a Termessian village and an economic centre of Termessian territory.

${ }^{84}$ İplikçioğlu 2007, 81-82; Rousset (2010, 110-115) suspects the Termessians mentioned in the Müğren inscription could be the Termessians at Oinoanda. This is very unlikely because firstly, Termessos/Oinoanda was already in Lycia by that time (as Rousset himself considers it in the Lycian Confederacy, p. 110). So it does not make sense to sign a border agreement between the Lycian league and one of its own members. Secondly, Pisidian Termessos' territory might well have extended to the Milyas region, see above pp. 102-103 and fns. 80-81. 


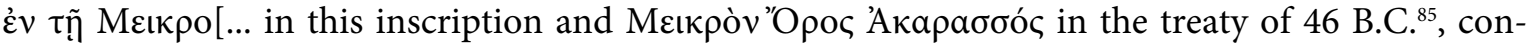
cludes that the border between Lycian and Termessian territories was just to the northeast of No-

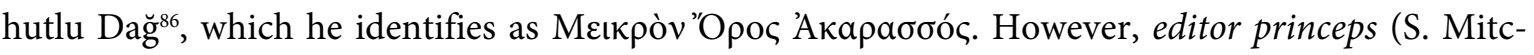

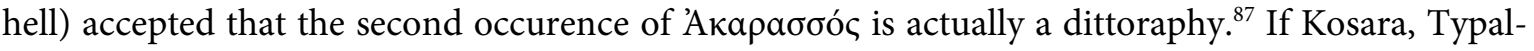
lia, Trebenna and Onobara were under Termessos by the reign of Claudius, the SP would probably not have mentioned them after Kitanaura, which would be the last station out of Lycia. Kosara is in a region called Mnarike, which cannot be a part of Termessian land, as this was not indicated in the SP. Typallia is known from an inscription to have been independent around 30 B.C. ${ }^{88}$ According to some inscriptions from the $3^{\text {rd }}$ century A.D. Typallia became depended on Termessos. ${ }^{89}$ Onobara was also in a sympoliteia lead by Trebenna at least in the $3^{\text {rd }}$ century A.D. ${ }^{90}$

The provincial affiliation of Kaunos, as well as that of Kibyra and Attaleia, has recently been debated. Marek pointed to the inclusion of Kaunos in Lycia by the Roman imperial period ${ }^{91}$ basing this upon the dating in the Hadrianic customs inscription from Kaunos ${ }^{92}$ which refers to the eponymous lykiarkhes Licinius Stasithemis ${ }^{93}$. Şahin and Adak had proposed that Kaunos was not included in the new province of Lycia when it was first established. ${ }^{94}$ Takmer asserted that the appearance of Kaunos in the customs inscription of Andriake is evidence for the inclusion of Kaunos in the new province of Lycia. ${ }^{95}$ I cannot say more on that since the exact context of the mention of Kaunos is not elaborated upon in the preliminary report. Marek rejected Şahin's opinion and reported that Kaunos was included in the new province of Lycia on the basis of several inscriptions, ${ }^{96}$ amongst which only the SP and the customs inscription of Andriake can be used as contemporary evidence for the provincia Lycia (all the other inscriptions he gives are from the Flavian period or later). With respect to the SP, he basically claimed that Kaunos was in Lycia by the time of Claudius, because it was given with no affiliation in the list, while Attaleia was shown as "of Pamphylia" and Kibyra was associated with Asia (as he had already stressed in IKaunos, 101). On the one hand, Marek is right to say that "Man muß bei den antiken geographischen Namen unterscheiden, ob sie sich auf landschaftliche oder politische Einheiten beziehen" (p. 57), on the other hand he creates confusion

${ }^{85}$ Mitchell 2005, 169, 1. 69 (AE 2005, no. 1487 = SEG LV 1452).

${ }^{86}$ Adak - Şahin 2004, 69; Şahin 2010b, 156: "In dieser Eigenschaft ist dieser Bergstock nicht nur eine Trennlinie zwischen den beiden Poljen, sondern auch eine natürliche Grenze zwischen Lykien und Asien, so daß die westlich gelegene Polje in Lykien, die östliche aber in Asien blieb." But according to the evidence, it is the border between Lycia and autonomous Termessos, not Asia, at least by the time of Claudius; cf. Şahin 2014, 221-223.

${ }^{87}$ Mitchell 2005, 215 and 221.

${ }^{88}$ Mitchell 1995 = SEG 44, 1113.

${ }^{89}$ İplikçioğlu - Çelgin - Çelgin 2001, 242-244; SEG 51, 1838-1839; Onur 2005, 9, fn. 33.

${ }^{90}$ Heberdey - Kalinka 1897, 37 no. 47; İplikçioğlu - Çelgin - Çelgin (n.d.), nos. 32-39; Onur 2005, 9, fn. 26.

${ }^{91}$ IKaunos, 101, 188-189.

${ }^{92}$ Bean 1954, 87-105 no. 38; IKaunos, 175-221 no. 35.

${ }^{93}$ For this Lyciarch see Reitzenstein 2011, 182-183, no. 28.

${ }^{94}$ Şahin - Adak 2007, 93 and 291; Şahin 2014, 423.

95 Takmer 2007, 173.

${ }^{96}$ Marek 2011. 
when he uses the term, "Provinz Pamphylia" (p. 58), which never existed as a political entity till the reign of Diocletianus. Adak, interpreting a new Flavian inscription from the Via Sebaste and with reference to the arguments of Marek and Takmer, noted the general conclusion that Kaunos was not a part of the Asian Province, but was included in that of Lycia from its establishment in A.D. 43. ${ }^{97}$ The latest contribution on the issue is from Şahin (2013). He thinks that the inclusion of Kaunos in Lycia should have started from the reign of Vespasianus, who newly created the provincia Lyciae et Pamphyliae, and that there is no clear evidence showing Kaunos was in Lycia before the Flavian period. As for the author, it is evident that none of the documents used in these arguments can prove that Kaunos was in the province of Lycia, perhaps except for the customs law in Andriake, where the context in which Kaunos is mentioned needs to be clarified. The passage of Dion Khrysostomos (31,50.124-125) mentioning the punishment of Kaunos, i.e. loss of the status of libera civitas, that probably took place in the reign of Vespasianus is also important in approaching this matter, since Kaunos might have kept this status during the Julio-Claudian period (also cf. Dräger 1993, 28-29 and fn. 13). I believe the Andriake inscription and a comparison with the customs law in Kaunos will lead us to a better understanding of the issue. So, at present I prefer to remain uncommitted before the full publication of the Andriake inscription.

\section{B. The settlements in Lycia and their political status in the SP}

The status of the settlements in the SP has been debated. Tietz concluded that all the settlements with no affiliation in the SP were independent, considering that the start and end points of routes were poleis and that the towns not mentioned in the SP, such as Daidala and Telandros (though they were on the route from Telmessos to Kaunos), were not independent poleis. ${ }^{98}$ Schuler on two occasions accepted that all the settlements in the SP had the status of a polis. In the first he reported

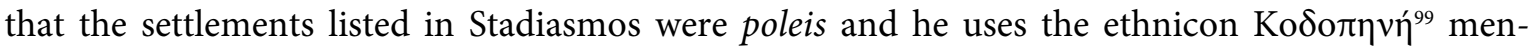
tioned in an inscription from Arykanda to show the independence of Kodopa ${ }^{100}$ His second remark is that if a settlement is not listed in the SP, even though it is actually located on the roads given in the SP, then it was not a polis in that time. ${ }^{101}$ This idea was not found plausible by Şahin, who thinks that not all the settlements in the SP were poleis, but some were already in the territory of other settlements, giving the examples of Kalabatia under Sidyma, Kosara under Mnara, and Onobara under Trebenna. ${ }^{102}$ Şahin is right to see difficulties in identifying the status of all the settlements as poleis. But I believe we should also be careful when we use evidence that is not contemporary with the SP, such as the inscriptions referring to "sympoliteia" dating mostly to the $2^{\text {nd }}$ or $3^{\text {rd }}$ centuries A.D. Furthermore, we do not know exactly how the system of "sympoliteia" worked, especially in terms of the political rights of the members, who seem to have maintained their independence to some

\footnotetext{
${ }^{97}$ Adak - Wilson 2012, 13-14.

98 Tietz 2003, 276 fn. 207; 292.

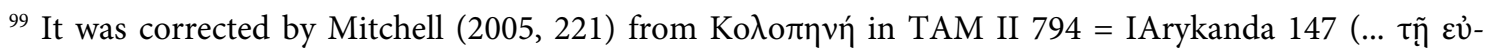

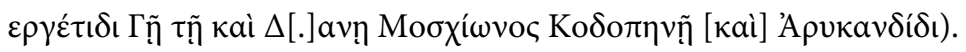

100 Schuler 2007, 77.

${ }^{101}$ Schuler 2010, 81 fn. 79.

${ }^{102}$ Şahin 2010a, 144 fn. 11.
} 
extent in administration, political organization and fiscal affairs. ${ }^{103}$ Consequently, being a member of a sympolity headed by another polis probably did not change the independent status of the member.

Although the SP does not give direct hints as to the status of the settlements mentioned, I also think that all the settlements in the SP were independent at least ot some extent. It was pointed out above that $\delta i \alpha$ + 'settlement name' in the genitive case without the article indicates the independence of the related settlement (see above p. 90). I consider this to be direct evidence of the attention paid to the status and territories of the settlements. Except for the five roads given above (see above p. 91), all the roads are between adjacent settlements and no road mentioned on the SP connects non-adjacent settlements without mentioning that it passed through the intermediate territory. In the SP, we can find further hints relating to this situation, including the omission of some ports such as Andriake. Different explanations have been proposed for this situation: for instance that the military priority of the roads, were built with military priorities not for economic, social and civic reasons, and so the roads did not lead to harbours unless the topography forced them to do so; ${ }^{104}$ or that access to these harbours was more convenient for ships and the SP focused on land routes; ${ }^{105}$ or that the harbours were not of polis status at the time of the SP. ${ }^{106}$ Actually this situation is not peculiar to ports. The SP never gives a road between two points within the same territory, or between a place in the territory of a major settlement and another settlement. Furthermore, at least five harbour settlements were mentioned in the SP: Telmessos, Patara, Gagai ${ }^{107}$, Korykos and Phaselis. Kalabatia might be a sixth, ${ }^{108}$ (see below pp. 108-109) and Antiphellos perhaps a seventh (see below). So it is also possible that the reason for the absence of some ports is that they were already within the territory of other settlements, as Andriake was within the territory of Myra.

The absence of Antiphellos from the SP seems complicated. But first it should be remembered that the destination of R 55, which is the second road from Phellos, could also be Antiphellos, and the reason that the destination was restored as Neisa by way of Kandyba by the editor ${ }^{109}$, was that the SP was supposed to have omitted ports. There is no direct evidence for the political status of Antiphellos in the Julio-Claudian period. Its absence from the SP may have been that Antiphellos was under the control of Phellos at that time, or the SP may simply have omitted it for an unknown reason. In the Classical period, Phellos ${ }^{110}$ was associated with a port. ${ }^{111}$ However it is not certain whether its

${ }^{103}$ Zimmermann 1992, 125 with fn. 10 (giving the examples of Olymos and Hydai under Mylasa), also 136 and $140-141$.

${ }^{104}$ Işı1k - İşkan - Çevik 2001, 47; Şahin 2014, 25.

${ }^{105}$ Mittenhuber 2009b, 62; see also Polla - Rinner 2009, 85-88.

${ }^{106}$ Schuler 2010, 81 fn. 79.

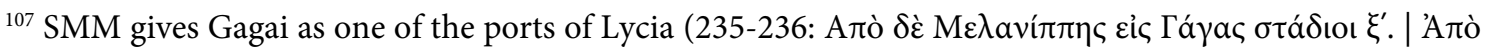

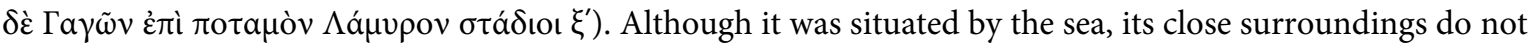
provide a good place for a port, but it probably had a one opposite Melanippe in the bay of Karaöz.

${ }^{108}$ Işık - İşkan - Çevik 2001, 47; Şahin 2014, 25.

${ }^{109}$ Şahin 2014, 336, 344-345.

${ }^{110}$ For the results of the field surveys around Phellos and the inscriptions see Zimmermann 2004a, 2004b, 2005a, 2005 b ve 2006 .

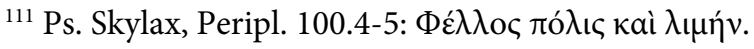


$\lambda \iota \mu \eta ́ v$ was at Kaş or Limanağzı/Bayındır Limanı (Sebeda?). ${ }^{112}$ The funerary inscriptions from the Roman imperial period around Asar Tepesi, Asar Gediği Tepesi, Bayındır and also Fakdere and Üzüm iskelesi on the southern shore indicate the control of Phellos over these territories. ${ }^{113}$ Accord-

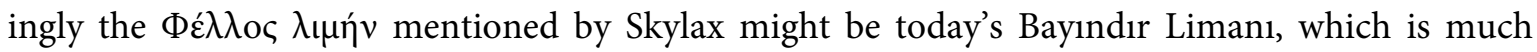
more practical and more convenient for sailing ships while Bucak Limanı was probably only suitable for small vessels and was dangerous for large sailing ships. ${ }^{114}$ Nevertheless, according to a bilin-

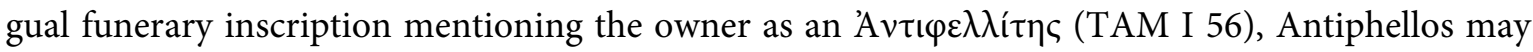
have been an independent settlement in $4^{\text {th }}$ century B.C. Although we do not know its exact status in the early imperial period, inscriptions indicate that Antiphellos was independent at least from the $2^{\text {nd }}$ century A.D. onwards. ${ }^{115}$ Bean thinks Antiphellos was a small settlement in the preHellenistic period. ${ }^{116}$ Furthermore, the coins from Antiphellos show its independence in the Hellenistic period. ${ }^{117}$ Alexandros Polyhistor (FHG Frg. 78-80 1.12) and Alexandros Polykharmos (FGH Frg. 4.3-4) show both Phellos and Antiphellos as poleis of Lycia in the $2^{\text {nd }}$ century B.C. Also in a Hellenistic inscription from Kos a certain Menophilos is shown as a citizen of Antiphellos. ${ }^{118} \mathrm{Zim}$ mermann mentions its development following its separation from Phellos, indicating its buildings including a theatre, bouleuterion, agora and necropolis that reflect its urban expansion during the Hellenistic Period. ${ }^{119}$ According to Bean following some later geographers (whom he does not cite), Antiphellos was the most important city in the area. ${ }^{120}$ But actually Strabon and Plinius, as the later geographers, did not give any remarkable information concerning Antiphellos. Strabon (14.3.7.6-7)

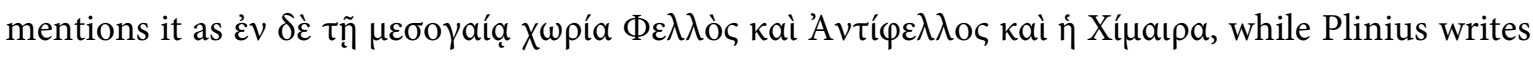
iuxta mare Limyra cum amne, in quem Arycandus influit, mons Masicytus, Andria civitas, Myra, oppida Aperlae et Antiphellos, quae quondam Habesos, atque in recessu Phellos (NH 5.43). Plinius also mentions the famous soft sponges found about walls of the city. ${ }^{121}$ An interesting funerary inscrip-

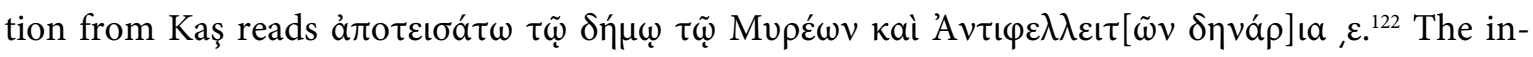
scription is dated to A.D. 149 when the eponym Veranius Tlepolemos ${ }^{123}$ was archiereus. The editors conjecture that there may have been a sympolity between Myra and Antiphellos following the earthquake of 141 A.D. ${ }^{124}$ However the editors of SEG approach this suggestion with suspicion. In

\footnotetext{
${ }^{112}$ See references and comments in Uzunoğlu - Taşdelen 2011, 83-84.

${ }^{113}$ Zimmerman 1992, 61-62; Uzunoğlu - Taşdelen 2011, 85 and 96 Fig. 2.

${ }^{114}$ Bean 1958, 56 fn. 24.

${ }^{115}$ See, e.g . TAM II 905: it was one the cities that Opramoas aided; IGR III 704: Antiphellos issued a decree for Iason of Kyaneai; cf. Uzunoğlu - Taşdelen 2011, 81-82.

${ }^{116}$ Bean 1958, 55.

${ }^{117}$ Kirsten 1985, 27-28; Zimmermann 1992, 187; Troxell 1982, 39, Pl. 4, nos. 21-23; Pl. 13, nos. 71-74.

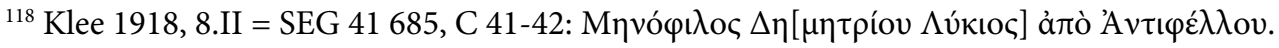

${ }^{119}$ Zimmermann 2006, 911; For more concerning the cultural and urban connections between Phellos and Antiphellos see Zimmermann 2005b, 248-250.

${ }^{120}$ Bean 1958, 55.

${ }^{121}$ Plin. NH 31.39: nunc autem mollissimae (spongiae) circa muros Antiphelli urbis reperiuntur.

122 Nollé - Sayar 1983, 219 No. 1 = AE 1987946 = SEG 331169.

${ }^{123}$ see Reitzenstein 2011, 203-204, no. 53, though she does not seem to have cited this inscription.

${ }^{124}$ Nollé - Sayar 1983, 220-221.
} 
any case, the absence of a connection to Antiphellos in the SP cannot be satisfactorily explained in the present state of evidence. This apparently requires some further research or we have to wait till the missing block, on which the destinations of the two roads from Phellos, one of which may have ended at Antiphellos, were recorded, is found at Patara.

Kalaba(n)tia is actually restored as the destination from Sidyma in R 3 of the SP, and is considered an exception by the editor princeps, who hypothetically explains the existence of this road connection with the military goal of Quintus Veranius to besiege Sidyma, where rebel forces might have taken shelter. ${ }^{125}$ But some of these explanations should be re-examined and I strongly recommend the following points for consideration in further research:

1) The restoration of Kalabatia is not secure. The editor princeps accepts the restoration of $\varepsilon[i \bar{c}$

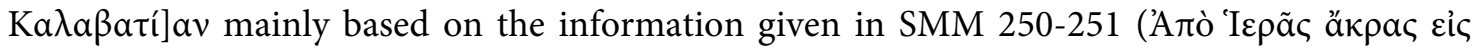

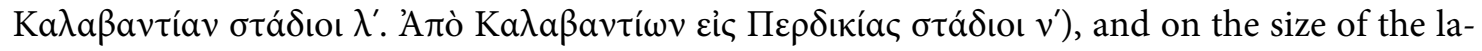
cuna on the inscription. ${ }^{126}$ The line 11 of face B (R 3) of the SP is inscribed almost a half-size smaller than the above and below lines, so $\mathrm{R} 3$ has a lacuna for more letters, which actually

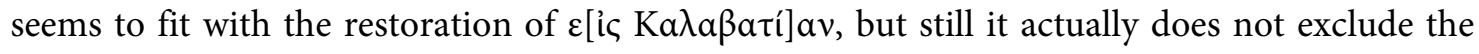
proposal of $\grave{\varepsilon}[\pi i ̀ \operatorname{á} \lambda \alpha \sigma \sigma] \alpha \nu$ or $\dot{\varepsilon}[\pi \grave{i} \tau \eta \dot{\nu} v \theta a ́ \lambda \alpha \sigma \sigma] \alpha v^{127}$, something that had already occurred in $\mathrm{R}$ 48 of the SP (see above pp. 96).

2) If the restoration of Kalabatia is correct, the status of Kalabatia should be better clarified. Kalabatia might have been an independent settlement (though perhaps not a polis) by the reign of Claudius. The use of the ethnicon in inscriptions might be considered evidence for the inde-

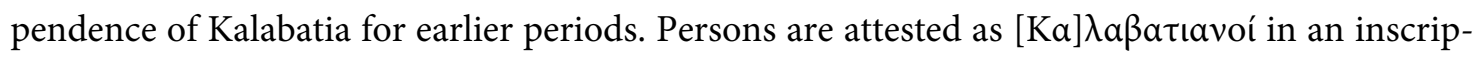
tion from Sidyma. ${ }^{128}$ This inscription's oracle section, where the "Kalabatians" are mentioned, is dated to the mid- $1^{\text {st }}$ century A.D. at the latest. ${ }^{229}$ The other is a recently published funerary

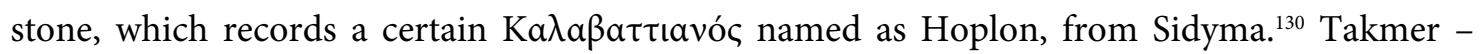
probably based on the forms of the letters - dates the inscription to the second half of the $2^{\text {nd }}$ century A.D. But the inscription clearly shows earlier features in terms of letter types which resemble those of the SP (for instance the curve of the cross lines of the sigmas). With a similar approach, Schuler considered Kodopa a polis, based on the use of its ethnicon in a funerary inscription at Arykanda (see above fns. 99-100).

3) The localisation of Kalabatia at Sancakl1 Liman1 ${ }^{131}$ is not certain, since there is no evidence relating to Kalabatia from the settlement in Sancakl. What we can surely say is that the ancient

${ }^{125}$ For the reasons stated in support of the construction of this connection, see Şahin 2009; Şahin 2014, 140-141.

${ }^{126}$ Şahin - Adak 2007, 128; Şahin 2009, 102-103; Şahin 2014, 139.

${ }^{127}$ Cf. Şahin 2009, 103.

${ }^{128}$ TAM II 174 1. E1; Merkelbach 2000; Merkelbach - Stauber 2002, 31 no. 17/08/01 1. 97.

129 The inscription incorporating this oracle is dated to the second half of $2^{\text {nd }}$ century, see Merkelbach 2000 125; Merkelbach - Stauber 2002, 33; Takmer 2010, 113 with fn. 159; Reitzenstein 2011, 76 with fn. 8.

130 Takmer 2010, 120 no. 3.

${ }^{131}$ Şahin - Adak 2007, 128-129; Şahin 2009, 103; Takmer 2010, 113; Şahin 2014, 139-140. 
port at Sancaklı belonged to Sidyma in the $2^{\text {nd }}$ and $3^{\text {rd }}$ centuries A.D. as the tomb violation fines were to be paid to Sidyma. ${ }^{132}$

4) The distance given for R 3 (Sidyma - [Kalabati]a) in the SP is 24 stadia, namely $4,5 \mathrm{~km}$. This length cannot fit with the actual distance between Sidyma and Sancaklı Liman1, which is around 7-8 km, a point also stressed by Şahin. ${ }^{133}$

\section{Conclusion}

The relations between roads, settlements and territories are especially important for the on-going field researches on the Roman roads in Lycia. On field surveys, I believe, we must now be even more careful searching the roads between settlements, since the distances in the SP should indicate the measurements between the town zones. There are still many issues to be solved through these field surveys, such as the matter of Sidyma and Kalabatia, Antiphellos and Phellos, Boubon and Trimilinda, Termessians at Oinoanda and Tlos (and the issue of Mount Masa between these two), Termessos and Lycia. It is important to understand the geographical and territorial relations between settlements and other administrative units (other provinces or powers) through the SP in the Claudian period, when Lycia was organised as a Roman province, since most of the roads are between adjacent settlements and the SP informs us if the territory of another settlement lay on the way. This also indicates the independent nature of the settlements recorded in the SP.

\section{Bibliography}

Adak 2004

Adak - Şahin 2004

Adak - Wilson 2012

M. Adak, Lokalisierung von Olympos und Korykos in Ostlykien. Gephyra, 1, 27-51.

M. Adak - S. Şahin, Das römische Strassen- und Siedlungssystem in der lykischen Milyas (Elmalı - Hochebene), Gephyra 1, 2004, 67-83.

M. Adak - M. Wilson, Das Vespasiansmonument von Döşeme und die Gründung der Doppelprovinz Lycia et Pamphylia, Gephyra 9, 2012, 1-40.

Akyürek Şahin et al. 2016 N. E. Akyürek Şahin - F. Onur - M. Alkan - M. E. Yıldız, Likya/Pamfilya Ulaşım Sistemleri Yüzey Araştırması 2015, ANMED 14, 2016 (in print).

Alkan 2011

M. Alkan, Parerga to the Stadiasmus Patarensis (8): On the named places in the journeys of sacrifice recorded in the Vita of Saint Nicholas of Holy Sion, Gephyra 8, 2011, 99-124.

Alkan 2013

M. Alkan, Toponym Olarak "Symbolon" ve Lykia'daki İki Lagün, in: N. E. Akyürek Şahin - B. Takmer - F. Onur (edd.), Eskiçağ Yazıları 5 [Akron 7], İstanbul 2013, 83-101.

Arslan 2007

M. Arslan, Mithradates VI Eupator: Roma'nın Büyük Düşmanı, İstanbul 2007.

\footnotetext{
132 TAM II 249-253.
}

${ }^{133}$ Şahin 2014, 137. 
Bean 1954

Bean 1958

Bean 1971

Biagi 2008

Corsten 2007

Corsten 2013

Corsten - Hülden 2012

Coulton 1982

Coulton 2012

Çelgin 2009

Çelgin 2013

Çevik 2015

Çevik - Pimouguet-Pédarros 2010

Çevik - Pimouguet-Pédarros 2013

Dräger 1993
G. E. Bean, Notes and Inscriptions from Caunus II, JHS 74, 1954, 85-110

G. E. Bean, Die Lage von Phellos, Anz. ÖAW 95, 1958, 49-58.

G. E. Bean, Journeys in Northern Lycia 1965-1967, Vienna 1971.

S. Biagi, Le stadiasmos de Patara et la définition de l'espace romain dans la nouvelle province de Lycie-Pamphylie, Res Antiquae 5, 2008, 299-307.

Th. Corsten, Kibyra und Lykien, in: Ch. Schuler (ed.), Griechische Epigraphik in Lykien. Eine Zwischenblanz. Akten des int. Kolloquiums, München, 24-26. Februar, Vienna 2007, 175-181.

Th. Corsten, Termessos in Pisidien und die Gründung griechischer Städte in Nord-Lykien, in: P. Brun - L. Cavalier - K. Konuk - F. Prost (edd.), Euploia. La Lycie et la Carie antiques. Actes du colloque de Bordeaux 5, 6, 7 novembre 2009, Bordeaux 2013, 77-83.

Th. Corsten - O. Hülden, Zwischen den Kulturen. Feldforschungen in der Kibyratis. Bericht zu den Kampagnen 2008-2011. Mit Beiträgen von Jörg Gebauer und Kathrin B. Zimmer, Ist.Mit. 62, 2012, 7-117.

J. J. Coulton, Termessians at Oinoanda, AS 32, 1982, 115-131.

J. J. Coulton, Balboura Survey and Settlement in Highland Southwest Anatolia I-II, London 2012.

A. V. Çelgin, Termessos Teritoryumu, Rudolf Heberdey ve Bir Toponim Önerisi Hakkında Değerlendirmeler, in: O. Tekin - A. Erol (edd.), Ancient History, Numismatics and Epigraphy in the Mediterranean World. Studies in memory of Clemens E. Bosch and Sabahat Atlan and in honour of Nezahat Baydur, Istanbul 2009, 99-111.

A. V. Çelgin, Termessos Teritoryumundan Yeni Bir Adak Yazıtı, in: O. Tekin - M. H. Sayar - E. Konyar (edd.), Tarhan Armağanı. M. Taner Tarhan'a Sunulan Makaleler / Essays in Honour of M. Taner Tarhan, Istanbul 2013, 115-129.

N. Çevik, Lykia Kitabı, İstanbul 2015.

N. Çevik - I. Pimouguet-Pédarros, Fortifications et système défensif de Myra: Recherches 2009, Anatolia Antiqua 18, 2010, 243-275.

N. Çevik - I. Pimouguet-Pédarros, Kelbessos et Kitanaura sur le territoire de Termessos de Pisidie, in: H. Bru - G. Labarre (edd.), L'Anatolie des peuples, cités et cultures (IIe millénaire av. J.-C.-Ve siècle ap. J.-C.). Autour du projet d'Atlas historique et archéologique de l'Asie Mineure antique. Actes du colloque international de Besançon (26-27 novembre 2010), Besançon 2013, 273-288.

M. Dräger, Die Städte der Provinz Asia in der Flavierzeit [Studien zur kleinasiatischen Stadt- und Regionalgeschichte, Bd. 576], 
DRGA

FGH

Gander 2014

Goodchild 1950

Graßhoff - Mittenhuber 2009

Harrison 1858

Harrison 2001

Heberdey 1929

Heberdey 1934

Heberdey - Kalinka 1897

Hellenkemper - Hild 2004

Hülden 2010

Işık - İşkan - Çevik

2001

İplikçioğlu 1999

İplikçioğlu 2004

İplikçioğlu 2007
Frankfurt am Main etc. 1993.

W. Smith (ed.), A Dictionary of Roman and Greek antiquities, London 1860.

K. W. Müller, (ed.), Fragmenta historicorum Graecorum, Paris 1841-1870.

M. Gander, Tlos, Oinoanda and the Hittite Invasion of the Lukka lands. Some Thoughts on the History of North-Western Lycia in the Late Bronze and Iron Ages, Klio 96/2, 2014, 369-415.

R. G. Goodchild, Roman Milestones in Cyrenaica, PBSR 18, 1950, 83-91.

G. Graßhoff - F. Mittenhuber (edd.), Untersuchungen zum Stadiasmos von Patara: Modellierung und Analyse eines antiken geographischen Streckennetzes, Bern 2009.

G. Harrison, A treatise on the Greek prepositions, and on the cases of nouns with which these are used, Philadelphia 1858.

M. Harrison, Mountain and Plain: from the Lycian Coast to the Phrygian Plateau in the Late Roman and Early Byzantine Period, (ed. W. Young), Ann Arbor 2001.

R. Heberdey, Termessische Studien [Akademie der Wissenschaften in Wien. Philosophisch-historische Klasse.], Vienna/Leipzig 1929.

R. Heberdey, Termessos, in: RE 5 A/1, 1934, 732-775.

R. Heberdey - E. Kalinka, Bericht über zwei Reisen im südwestlichen Kleinasien, Vienna 1897.

H. Hellenkemper - F. Hild, Lykien und Pamphylien I-III [Tabula Imperii Byzantini 8; Österreichische Akademie der Wissenschaften. Philosophisch-historische Klasse. Denkschriften 320], Vienna 2004.

O. Hülden, Die Nekropolen von Kyaneai. Studien zur antiken Grabkultur in Lykien II [Lykische Studien 9/2, Tübinger Althistorische Studien 5/2], Bonn 2010.

F. Işık - H. İşkan - N. Çevik, Miliarium Lyciae. Patara Yol Kılavuz Anitı / Das Wegweisermonument von Patara, Lykia IV 1998/1999, İstanbul 2001.

B. İplikçioğlu, Zum Territorium von Termessos in Pisidien, in: P. Scherrer - H. Täuber - H. Thür (edd.), Steine und Wege. Festschrift für Dieter Knibbe zum 65. Geburtstag, Vienna 1999, 309-314.

B. İplikçioğlu, Ländliche Siedlungen und das Territorium von Termessos (Pisidien), in: F. Kolb - E. Müller-Luckner (edd.), Chora und Polis [Schriften des Historischen Kollegs, Kolloquien 54], Munich 2004, 103-125.

B. İplikçioğlu, Entscheidung eines Statthalters von Lykien in einem Rechtsstreit zwischen Termessos und dem Koinon der Lykier, in: Ch. Schuler (ed.), Griechische Epigraphik in Lykien, Eine Zwi- 
schenblanz. Akten des int. Kolloquiums, München, 24-26. Februar, Vienna 2007, 81-83.

İplikçioğlu - Çelgin - Çelgin $\quad$ B. İplikçioğlu - G. Çelgin - A. V. Çelgin, Doğu ve Kuzeydoğu 2001 Lykia-Güneybatı Pisidia Epigrafik-Tarihi Coğrafi Yüzey Araştırmaları Projesi 1999, AST 18, 2001, 242-244.

İplikçioğlu - Çelgin - Çelgin $\quad$ B. İplikçioğlu - G. Çelgin - A. V. Çelgin, Epigraphische Forschun(n.d.)

\section{Kirsten 1985} gen in Termessos und seinem Territorium IV: Epigraphische Forschungen in Ostlykien. Forschungsjahr 1999. (unpublished article).

E. Kirsten, Phellos und Antiphellos, in: M. Kandler - S. Karwiese R. Pillinger (edd.), Lebendige Altertumswissenschaft, Festgabe zur Vollendung des 70. Lebensjahres von Hermann Vetters, Vienna 1985, 24-29.

Klee 1918

T. Klee, Zur Geschichte der gymnischen Agone an griechischen Festen, Leipzig/Berlin 1918.

Kokkinia 2008

Ch. Kokkinia (ed.), Boubon: The Inscriptions and Archaeological Remains; A Survey 2004-2006 [Meletemata 60], Athens 2008.

Kokkinia 2008a

Ch. Kokkinia, The Inscriptions of Boubon: a cataloque, in: Kokkinia 2008, 27-126.

Kolb 1995

F. Kolb, Kyaneai ve Çevresi Yüzey Araştırması 1994 Yılı Sonuçları, AST XIII/1, 1995, 245-269.

Kolb 2008

F. Kolb, Burg - Polis - Bischofssitz. Geschichte der Siedlungskammer von Kyaneai in der Südwesttürkei, Mainz am Rhein 2008.

Korkut 2014

T. Korkut, Tlos Antik Kenti ve Çevresi Yüzey Araştırmaları, AST 32/1, 2014, 505-524.

Korkut 2015

Lebreton 2010

T. Korkut, Tlos, İstanbul 2015.

S. Lebreton, Les géomètres de Quintus Veranius. À propos du stadiasmos de Patara, Dialogues d'histoire ancienne 36/2, 2010, 61116.

Lex. Corn. Schrev.

C. Schrevel, Lexicon manuale græco-latinum et latino-græcum, New York 1832.

Luraghi 2003

S. Luraghi, On the meaning of prepositions and cases: the expression of semantic roles in ancient Greek, Amsterdam 2003.

Luraghi 2012

S. Luraghi, The Spatial Meaning of $\delta$ tá with the Accusative in Homeric Greek, Mnemosyne 65/3, 2012, 357-386.

Marek 2011

Ch. Marek, Kaunos und Lykien, Adalya 14, 2011, 57-60.

Marksteiner - Wörrle 2002

T. Marksteiner - M. Wörrle, Ein Altar für Kaiser Claudius auf dem Bonda, Chiron 32, 2002, 545-564.

Mattingly 1997

H. B. Mattingly, The Date and Significance of the 'Lex Antonia de Termessibus', Scholia: Studies in Classical Antiquity 6, 1997, 68-78.

McNicoll - Winikoff 1983

A. McNicoll - T. Winikoff, A Hellenistic Fortress in Lycia-The Isian Tower?, AJA 87/3, 1983, 311-323. 
Merkelbach 2000

Merkelbach - Stauber 2002

Milner - Eilers 1995

Milner - Eilers 2006

Mitchell 1995

Mitchell 2005

Mittenhuber 2009a

Mittenhuber 2009b

Mittenhuber 2009c

Nollé 1996

Nollé - Sayar 1983

Nov. Lex. Man.

OGIS

Onur 2005

Onur 2016

Onur - Alkan 2011
R. Merkelbach, Der Glanz der Städte Lykiens. Die Festrede des Literaten Hieron (TAM II 174), EpigrAnat 32, 2000, 115-125.

R. Merkelbach - J. Stauber, Steinepigramme aus dem griechischen Osten IV: Die Südküste Kleinasiens, Syrien und Palaestina, Münih/ Leipzig 2002.

N. P. Milner - C. F. Eilers, Q. Mucius Scaevola and Oenoanda: A New Inscription, AS 45, 1995, 73-89.

N. P. Milner - C. F. Eilers, L. Calpurnius Piso, Moles Son of Moles, and Emperor Worship: Statue Bases from the Upper Agora at Oinoanda, AS 5, 2006, 61-76.

S. Mitchell, Termessos, king Amyntas, and the war with the Sandaliôtai. A new inscription from Pisidia, in: D. French (ed.), Studies in the History and Topography of Lycia in Memoriam A. S. Hall, London 1995, 95-105.

S. Mitchell, The Treaty between Rome and Lycia of 46 BC (MS 2070), in: R. Pintaudi (ed.), Papyri Graecae Schøyen [Papyrologica Florentina 35], Firenze 2005, 164-259.

F. Mittenhuber, Literarischer und geographischer Kontext, in: Graßhoff - Mittenhuber 2009, 7-29.

F. Mittenhuber, Untersuchungen zum Stadiasmos von Patara: Modellierung und Analyse eines antiken geographischen Streckennetzes, in: Graßhoff - Mittenhuber 2009, 27-62.

F. Mittenhuber, Identifizierung und Lokalisierung der im Stadiasmos aufgeführten Orte, in: Graßhoff - Mittenhuber 2009, 89-147.

J. Nollé, Kitanaura: Münzen und Geschichte einer kleinen Stadt in den ostlykischen Bergen, JNG 46, 1996, 7-29.

J. Nollé - M. H. Sayar, Drei Inschriften aus Antiphellos in Lykien, ZPE 52, 1983, 219-223.

B. Hederich, Novum lexicon manuale Graeco-Latinum et LatinoGraecum, Leipzig 1827.

W. Dittenberger (ed.), Orientis Graeci Inscriptiones Selectae I-II, Leipzig 1903-1905.

F. Onur, Trebenna Tarihi / History of Trebenna, in: N. Çevik - E. Akyürek - B. Varkıvanç (edd.), Trebenna. Tarihi Arkeolojisi ve Doğası. Its History, Archaeology and Natural Environment, İstanbul 2005, 7-20 and 161-166.

F. Onur, Parerga to the Stadiasmus Patarensis (17): A Correction to the Course of the Road between Xanthos and Neisa, Gephyra 13, 2016, 211-224.

F. Onur - M. Alkan, Parerga to the Stadiasmus Patarensis (6): Route 54 (Patara - Phellos) and New Inscriptions, Gephyra 8, 2011, 64-80. 
Onur - Oktan 2013

Platner 1929

Polla - Rinner 2009

Porcher 2009

Reitzenstein 2011

Rinner 2009a

Rinner 2009b

Rivet - Jackson 1970

Robert 1963

Robert 1966

Robert 1983

Rodwell 1975

Rousset 2010

Rousset 2013

Salway 2007

Salway 2012
F. Onur - M. Oktan, Parerga to the Stadiasmus Patarensis (12): The routes 56 - 57 (Phellos - Kyaneai - Myra), Gephyra 10, 2013, 97-108.

S. B. Platner, A Topographical Dictionary of Ancient Rome, London 1929.

S. Polla - E. Rinner, Der Stadiasmos und das lykische Strassennetz, in: Graßhoff - Mittenhuber 2009, 63-88.

A. Porcher, Campagnes et habitats du territoire de Termessos (Pisidie): quelques repères pour l'époque impériale, in: $\mathrm{H}$. Bru - F. Kirbihler - S. Lebreton (edd.), L'Asie mineure dans l'antiquité: échanges, populations et territoires: regards actuels sur une péninsule: actes du colloque de Tours, 21-22 octobre 2005, Rennes Cedex 2009, 289-300.

D. Reitzenstein, Die Lykischen Bundespriester: Repräsentation der kaiserzeitlichen Elite Lykiens, Berlin 2011.

E. Rinner, Implizite Informationen des Stadiasmos zur Kreuzungssituation im Xanthostal, in: Graßhoff - Mittenhuber 2009, 167-207.

E. Rinner, Die Wiedergabe eines Strassennetzes in der Inschrift des Stadiasmos, in: Graßhoff - Mittenhuber 2009, 209-251.

A. L. Rivet - K. Jackson, The British Section of the Antonine Itinerary, Britannia 1, 1970, 34-82.

L. Robert, Noms indigènes dans l'Asie Mineure gréco-romaine, Paris 1963.

L. Robert, Documents de l'Asie Mineure méridionale, Genf - Paris 1966.

L. Robert, Documents de l'Asie Mineure, XXIII-XXVIII, BCH 107, 497-599.

W. Rodwell, Milestones, Civic Territories and the Antonine Itinerary, Britannia 6, 1975, 76-101.

D. Rousset, De Lycie en Cabalide: la convention entre les Lyciens et Termessos près d' Oinoanda [Fouilles de Xanthos X. Hautes études du monde gréco-romain 45], Geneva 2010.

D. Rousset, Le stadiasme de Patara et la géographie historique de la Lycie: itinéraires et routes, localités et cités, in: P. Brun - L. Cavalier - K. Konuk - F. Prost (edd.), Euploia. La Lycie et la Carie antiques. Actes du colloque de Bordeaux 5, 6, 7 novembre 2009, Bordeaux 2013, 63-75.

B. Salway, The perception and description of space in Roman itineraries, in: M. Rathmann (edd.), Wahrnehmung und Erfassung geographischer Räume in der Antike, Mainz am Rhein 2007, 181209.

B. Salway, Putting the World in Order: Mapping in Roman Texts, 
Schuler 1998

Schuler 2007

Schuler 2010

SMM

SNGBN

Şahin 2009

Şahin 2010a

Şahin 2010b

Şahin 2011

Şahin 2013

Şahin 2014

Şahin - Adak 2007

Takmer 2002

Takmer 2004

Takmer 2007

Takmer 2010

Tietz 2003

Troxell 1982

Tüner 2002 in: R. J. Talbert (ed.), Ancient Perspectives: Maps and their Place in Mesopotamia, Egypt, Greece, and Rome, Chicago 2012, 193-234.

Ch. Schuler, Ländliche Siedlungen und Gemeinden im hellenistischen und römischen Kleinasien [Vestigia 50], Münih 1998.

Ch. Schuler, Ein Vertrag zwischen Rom und den Lykiern aus Tyberissos, in: Ch. Schuler (ed.), Griechische Epigraphik in Lykien. Eine Zwischenblanz. Akten des int. Kolloquiums, München, 24-26. Februar, Vienna 2007, 51-79.

Ch. Schuler, Priester $\pi \rho o ̀ ~ \pi o ́ \lambda \varepsilon \omega \varsigma$ in Lykien: Eine neue Inschrift aus dem Territorium von Patara, ZPE 173, 2010, 69-86.

Stadiasmus sive periplus Maris Magni.

Sylloge Nummorum Graecorum Cabinet des Médailles, Banque Nationale de Paris.

S. Şahin, Parerga zum Stadiasmus Patarensis (1). Überlegungen zur Strecke 3 von Sidyma nach Kalabatia, Gephyra 6, 2009, 101-112.

S. Şahin, Parerga zum Stadiasmus Patarensis (3): Die Inschrift von Köybaşı in Zentrallykien, Gephyra 7, 2010, 137-152.

S. Şahin, Parerga zum Stadiasmus Patarensis (4): Mikron Oros Akarassos in Milyas, Gephyra 7, 2010, 153-159.

S. Şahin, Parerga zum Stadiasmus Patarensis (5). STR 59 und Daseia von Bonda, Gephyra 8, 2011, 55-63.

S. Şahin, Parerga zum Stadiasmus Patarensis (9): Kaunisch-lykische Frage, Gephyra 10, 2013, 32-37.

S. Şahin, Stadiasmus Patarensis. Itinera Romana Provinciae Lyciae / Likya Eyaleti Roma Yolları (Tarihi İçerik: M. Adak), Istanbul 2014.

S. Şahin - M. Adak, Stadiasmus Patarensis. Itinera Romana Provinciae Lyciae, Istanbul 2007.

B. Takmer, Lykia Orografyası, in: S. Şahin - M. Adak (edd.), Likya İncelemeleri 1, Istanbul 2002, 33-51.

B. Takmer, Two Milestones on the Road from Myra to Limyra. Gephyra 1, 2004, 107-117.

B. Takmer, Lex Portorii Provinciae Lyciae. Ein Vorbericht über die Zollinschrift aus Andriake aus neronischer Zeit, Gephyra 4, 2007, 165-188.

B. Takmer, Stadiasmus Patarensis için Parerga 2: Sidyma I. Yeni Yazıtlarla Birlikte Yerleşim Tarihçesi, Gephyra 7, 2010, 95-136.

W. Tietz, Der Golf von Fethiye, Bonn 2003.

H. A. Troxell, The Coinage of the Lycian League, New York 1982 (Numismatic Notes and Monographs 162).

N. Tüner, Lykia'nın Yerleşim Coğrafyasında Yeni Lokalizasyonlar, in: S. Şahin - M. Adak (edd.), Likya İncelemeleri I, Istanbul 2002, 
63-78.

Uzunoğlu - Taşdelen 2011 H. Uzunoğlu - E. Taşdelen, Parerga to the Stadiasmus Patarensis (7): New inscriptions from the territory of Phellos, Gephyra 8, 2011, 81-98.

Van Tilburg 2007

C. Van Tilburg, Traffic and Congestion in the Roman Empire, Abingdon 2007.

Wörrle 1988

M. Wörrle, Stadt und Fest im kaiserzeitlichen Kleinasien, Munich 1988.

Yılmaz - Çevik 1996

H. Yılmaz - N. Çevik, Tlos 1994, AST 13/1, 1996, 185-203.

Zimmermann 1992

Zimmermann 2004a

M. Zimmermann, Untersuchungen zur historischen Landeskunde Zentrallykiens, Bonn 1992.

M. Zimmermann, Feldforschungen in Phellos (Lykien) 2003, AST 22/1, 2004, 45-52.

Zimmermann 2004b

M. Zimmermann, Survey at Phellos 2003, ANMED 2, 2004, 101104.

Zimmermann 2005a

M. Zimmermann, Feldforschungen in Phellos (Lykien) 2004, AST 22/1, 2005, 63-68.

Zimmermann 2005b

M. Zimmermann, Eine Stadt und ihr kulturelles Erbe. Vorbericht über Feldforschungen im zentrallykischen Phellos 2002-2004, MDAI (I) 55, 2005, 211-266.

Zimmermann 2006

M. Zimmermann, Phellos in Zentrallykien und die Grundmuster lykischer Siedlungsgeschichte, şurada: K. Dörtlük - B. Varkıvanç T. Kahya - J. De Courtils - M. Doğan Alparslan - R. Boyraz (eds.), III. Uluslararası Likya Sempozyumu / The IIIrd Symposium on Lycia (07-10 Kasim 2005 / 07-10 November 2005, Antalya) Sempozyum Bildirileri / Symposium Proceedings, II. Cilt, İstanbul 2006, 907-916. 


\section{Stadiasmus Patarensis için Parerga (16): Yollar, Yerleşimler ve Teritoryumlar Özet}

$\mathrm{Bu}$ makalede Stadiasmus Patarensis'te (SP) geçen yollar, yerleşimler ve teritoryumlar arasındaki ilişkilere yönelik bazı hususlar tartışılmaktadır. SP’nin bir seyahat kılavuzu olamayacağını ve sadece, neredeyse bütün büyük ve bazı küçük yerleşimler arasında tamir edilen, yeniden yapılan ya da mevcut haldeki yolların (viae) uzunluklarının verildiği, fakat rotaları (itinera) gösterme amacı taşımayan bir liste olduğunu kabul eden yazar şunları önermektedir: 1) Yerleşimler arasındaki yolların mesafeleri yerleşim merkezlerinden ya da merkez sınırlarından ölçülmüş ve anıtta da o şekilde verilmiştir. 2) Yerleşimlerin teritoryumları SP'de dikkate alınmıştır. 3) SP'de adı geçen tüm yerleşimler, statü bakımından her zaman belirlenemese de bağımsız bir yapıya sahiptir. Bu üç öneri üç başlıkla açıklanmaktadır.

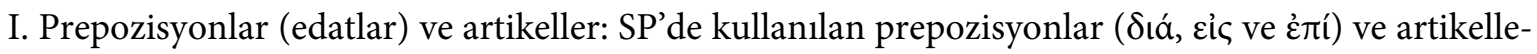
rin kullanımındaki belli özellikler metni coğrafi olarak kavramada önem arz etmektedir. Bu bağ-

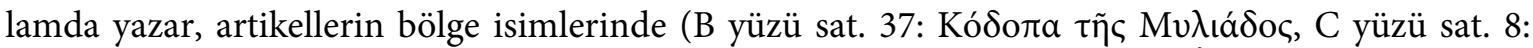

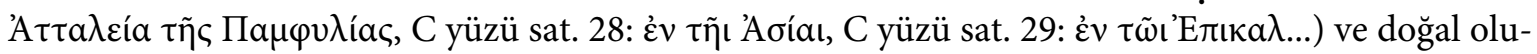

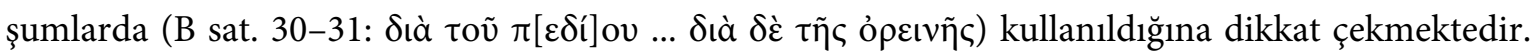
$\Delta ı$ á prepozisyonu alıp, artikelle verilen diğer isimlerin doğal oluşumlara (örn. ovalık alan, dağlık alan) ve dağa (örn. Masikytos), artikel almayan isimlerin ise (Trimilinda, Plata..., Kollyba, Kandyba,

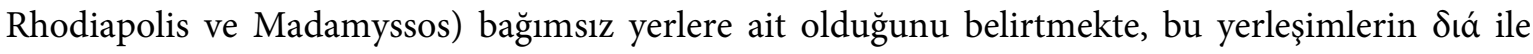
gösterilmesinin nedenini de yolun yerleşimin içine girmeden teritoryumundan geçmesiyle açıklamaktadır. Bu durumda yazar, yolların eiç alan yerleşimlere girdiğini ve bu yolların ölçülerinin kentin merkez sınırlarından itibaren alındığını savlamaktadır.

II. Mesafeler ve yerleşimler: SP’nin bir seyahat rehberi gibi bir amacının olmadığı ve sadece yol ölçülerinin resmi bir sunumu olduğu kabul edilerek, verilen ölçülerin özenli olduğu ve yolların doğrudan ilgili yerleşimlerden çıkıp diğer yerleşimin içine ulaştı̆̆ belirtilmektedir. Phellos - Kyaneai Myra yolları ile Rhodiapolis ve Madamyssos arazilerinden geçerek giden Korydalla - Akalissos yolu bu tez için örnek olarak kullanılmaktadır. Bu örnekler uyarınca, Phellos'tan çıkan yolun Kyaneai kentine gitmeyip hemen güneyindeki ovadan ilerleyerek Myra'ya gitmiş olması, SP’te belirtilen yol ölçülerinin veriliş sistematiği açısından uyumsuz olmaktadır. Çünkü böyle bir durumda, yol Kyane-

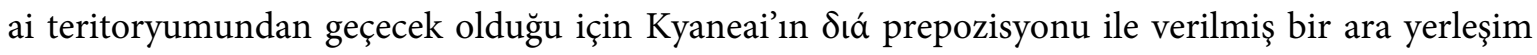
olarak görünmesi gerekecekti. Bunun böyle olması gerektiği, Korydalla'dan çıkıp Akalissos’a ilerle-

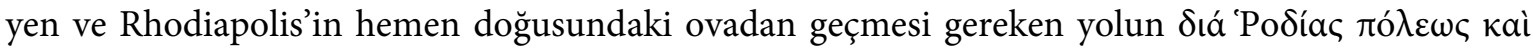

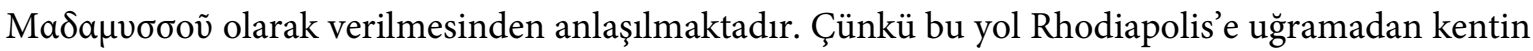

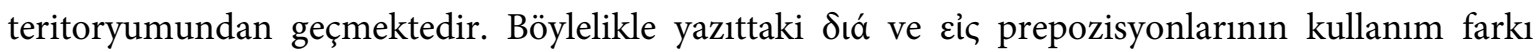
daha belirgin bir şekilde görülebilmektedir.

III. Yerleşimlerin statüleri ve teritoryumları: SP’te geçen yerleşimlerin hepsinde bağımsız bir yapıya sahip olduğu gerek yukarıdaki tartışmalardan gerekse bazı yerleşimlerin verilmemiş olmasından anlaşılabilmektedir. Bunun yanı sıra Kitanaura'nın Termessos'a bağlı verilmesi de özerkliklerin dikkate alınmış olmasına bir örnektir. SP'nin aynı teritoryum içerisinde bulunan herhangi iki nokta arasında hiç yol vermemesi de bu durumla ilişkilidir. Bu duruma aykırı görülebilecek tek yol bilgisi Sidyma ve Kalaba(n)tia arasında gösterilen yoldur. Fakat bu yol bilgisinin gözden geçirilmesi gereken önemli hususları vardır: 1- Yazıttaki Kalaba(n)tia tamamlaması kesin değildir; 2- Eğer Kalaba(n)tia tamamlaması doğru ise, SP’nin sistematiğine göre Kalaba(n)tia'nın statüsünün bağımsız 
bir yapıya sahip olması beklenir; 3- Kalabatia'nın Sancaklı Limanı'ndaki lokalizasyonu kesin değildir, çünkü Sancaklı limanından Kalabatia'ya ilişkin kesin bir veri olmamakla birlikte, Sancaklı limanının İ.S. 2.-3. yüzyıllarda Sidyma’ya ait bir liman olduğu kesindir; 4- Sidyma - Kalaba(n)tia arasında verilen mesafe SP'de 24 stadia $(4,5) \mathrm{km}$ iken, Sidyma ve Sancaklı limanı arasındaki gerçek mesafe 7-8 km'dir. Sonuç olarak, yollar, yerleşimler ve teritoryumlar arasındaki ilişkiler devam eden yüzey araştırmaları açısından oldukça önemlidir.

Anahtar Sözcükler: Stadiasmus Patarensis; Roma Yolları; artikeller; edatlar; yerleşim statüleri; yerleşim teritoryumları.

\section{Parerga to the Stadiasmus Patarensis (16): The Roads, Settlements and Territories Abstract}

In this contribution the author discusses three issues relating to the course of the roads and settlements mentioned in the Stadiasmus Patarensis (SP): 1- All the roads recorded on the SP were measured from within the borders of town centres, except for those settlements given with the preposition $\delta$ iá. 2- The territories of the settlements were observed in the composition of the road list and indicated through $\delta$ iá when required. 3- All the settlements recorded on the SP had an independence with reference to fiscal basis and possessed territorial rights. The author begins the discussion with the use of the prepositions $\delta \dot{\prime a ́}, \varepsilon i \zeta$ and $\dot{\varepsilon} \pi$ í, which relate to territories or natural formations, town zones and borders respectively, and the articles that were not used for the settlement names, but for the regions or natural formations recorded on the SP. The author understands the SP was not constructed as a route guide for travellers, as it does not provide "routes" (itinera) but "roads" (viae) and, in consequence, it should be regarded as an official inventory of the roads, and consequently it is suggested that the recorded distances indicate the actual lengths of the roads between the borders of town-zones. Finally, based upon the argumentation outlined above, the author points out the independent nature of the settlements recorded in the SP. He also discusses the possible reasons for the omission of some ports, and concludes that it was because they were either, not poleis at the time or, they were ports under the control of other settlements, such as Andriake of Myra, with the roads given to the cities to which these ports belonged.

Keywords: Stadiasmus Patarensis; Roman Roads; articles; prepositions; status of settlements; territories of settlements. 